\title{
SEKVESTRACIJA NEKRETNINE U SVJETLU ZAS̆TITE PRAVA NA MIRNO UŽIVANJE IMOVINE
}

Izv. prof. dr. sc. Gabrijela Mihelčić*

Doc. dr. sc. Maša Marochini Zrinski**

\author{
UDK: 347.233 \\ https://doi.org/10.30925/zpfsr.40.1.8 \\ Ur.: 28. siječnja 2019. \\ Pr.: 15. veljače 2019. \\ Izvorni znanstveni rad
}

\begin{abstract}
Sažetak
Autorice u radu analiziraju institut privremene uprave na nekretnini u općem $i$ odabranim posebnim režimima. U prvom dijelu rada daje se prikaz geneze instituta, a zatim promatraju njegove pretpostavke iobilježja. Istaknuti suzahtjevi potrebni za uspostavljanje privremene uprave u nacionalnom uređenju, tj. da je od vlasnika zatraženo određeno činjenje koje je on uskratio, a u povodu zaštite određenih dobara. Zatim su analizirana obilježja privremenosti i ograničenja izvršavanja vlasničkopravnih ovlasti na stvari analizirana s obzirom na značajke zaštite prava na mirno uživanje imovine. Istaknuto je da se radi o trećem pravilu o kontroli korištenja imovine i promatralo se je li određenim uređenjem narušena pravična ravnoteža, odnosno jesu li ograničenja koja je država nametnula u okviru polja slobodne procjene razmjerna (proporcionalna).
\end{abstract}

Ključne riječi: privremena uprava; pravo na mirno uživanje imovine; razmjernost.

\section{1. $U$ VOD}

Jedno od prvih obilježja privremene uprave (sekvestracije) jest da njezinom uspostavom dolazi do ograničenja prava vlasništva, no, do njega ne dolazi u građanskom postupku niti pred redovnim sudovima. Usprkos tomu, nema zapreke da se, sukladno razvijenoj doktrini, tzv. građanskih prava i obveza ${ }^{1}$ artikuliranoj u povodu zaštite prava na pošteno suđenje iz članka 6 . Konvencije za zaštitu ljudskih prava i temeljnih sloboda, ${ }^{2}$ njezine pretpostavke ne provjere u svjetlu zaštite prava na

* Dr. sc. Gabrijela Mihelčić, izvanredna profesorica, Sveučilište u Rijeci, Pravni fakultet; gabrijela@pravri.hr.

** Dr. sc. Maša Marochini Zrinski, docentica, Sveučilište u Rijeci, Pravni fakultet; mmarochini@ pravri.hr.

1 Grbić, S., Pošteno suđenje u građanskim postupcima u Hrvatskoj u svjetlu članka 6., stavka 1. Europske konvencije o ljudskim pravima, Rijeka, Pravni fakultet u Rijeci, 2014., str. 16 et seq., Stažnik, Š., Europski sud za ljudska prava i standardi upravnosudskog postupka, u: Europeizacija upravnog sudovanja u Hrvatskoj (ured. I. Koprić), Zagreb, Institut za javnu upravu, 2014., str. 127-129.

2 Narodne novine (dalje u tekstu: NN), Međunarodni ugovori (dalje u tekstu: MU), br. 18/97, 6/99 
mirno uživanje imovine. ${ }^{3}$ Odgovor na pitanje o pretpostavkama traženim za uspostavu privremene uprave najprije daju odredbe našeg općeg stvarnopravnog uređenja iz članka 32. Zakona o vlasništvu i drugim stvarnim pravima. ${ }^{4}$ Ako je zbog zaštite interesa i sigurnosti države, prirode, spomenika kulture, ljudskoga okoliša ili zdravlja ljudi zakonom predviđeno da je vlasnik dužan nešto poduzeti u pogledu stvari, a ne može ga se na to prisiliti može se na stvari uspostaviti privremena uprava (članak 32. stavak 3. ZV-a). Osim ovog uređenja, postoje i ona iz posebnih propisa ${ }^{5}$ koja se često i drukčije nazivaju, no, dijele zajedničko obilježje da je vlasnik trebao nešto učiniti, pa nije, zbog čega je ograničen u izvršavanju svojih vlasničkopravnih ovlasti na stvari. $\mathrm{U}$ ovom radu se analizira uređenje privremene uprave na nekretninama, a pored općeg uređenja, promatra se posebno uređenje poljoprivrednog zemljišta ${ }^{6} \mathrm{i}$ nepokretnih kulturnih dobara. ${ }^{7}$

Ograničenja prava vlasništva u konvencijskoj praksi ispituju se, ponajprije, kroz povrede prava na mirno uživanje imovine. ${ }^{8} \mathrm{U}$ vezi s njim države uživaju široko polje

- pročišćeni tekst, 8/99, 14/02, 13/03, 9/05, 1/06, 2/10 i 13/17 (dalje u tekstu: Konvencija ili EKLJP).

3 Bogdanović navodi da se zaštita prava iz članka 1. Protokola broj 1. uz Konvenciju (dalje u tekstu: članak 1. Protokola 1.) može pružiti u upravnom sporu. Bogdanović, T., Zaštita prava vlasništva iz članka 1. Protokola 1. Europske konvencije u praksi Upravnog suda Republike Hrvatske, Zbornik Pravnog fakulteta Sveučilišta u Rijeci, vol. 32, 1/2011., str. 584.

$4 \mathrm{NN}$, br. 91/96, 68/98, 137/99, 22/00, 73/00, 129/00, 114/01, 79/06, 141/06, 146/08, 38/09, 153/09, 143/12, 152/14, 81/15 - pročišćeni tekst i 94/17, dalje u tekstu: ZV. U njegom prvom stavku predviđeno je da, zbog zaštite interesa i sigurnosti države, prirode, ljudskoga okoliša i zdravlja ljudi, vlasnik svoje pravo vlasništva ne smije izvršavati preko granica postavljenih zakonom za sve vlasnike takve stvari. Stvar se na temelju Ustava Republike Hrvatske, NN, br. 56/90, 135/97, 8/98, 113/00, 124/00, 28/01, 41/01, 55/01, 76/10, 85/10 i 5/14, dalje u tekstu: Ustav, može posebnim zakonom proglasiti od interesa za Republiku Hrvatsku te za nju, vlasnicima i ovlaštenicima drugih prava odrediti poseban način uporabe i iskorištavanja. U tom se slučaju vlasništvo izvršava s ovim u skladu, a vlasniku pripada naknada zbog ograničenja kojima je podvrgnut (članak 32. stavak 2. ZV-a).

5 Npr. u: Zakonu o poljoprivrednom zemljištu, NN, br. 20/18 i 115/18, dalje u tekstu: ZPZ, Zakonu o zaštiti i očuvanju kulturnih dobara, NN, br. 69/99, 151/03, 157/03, 100/04, 87/09, 88/10, 61/11, 25/12, 136/12, 157/13, 152/14, 98/15 i 90/18 (dalje u tekstu: ZZOKD), Zakonu o šumama, NN, br. 68/18 (dalje u tekstu: ZŠ), Zakonu o zaštiti prirode, NN, br. 80/13 i 15/18 (dalje u tekstu: ZZP), Zakonu o građevinskoj inspekciji, NN, br. 153/13 (dalje u tekstu: ZGI) i dr.

6 Članak 14. stavak 1. ZPZ-a dopušta da se zbog zaštite tla, okoliša ili ljudi, poljoprivredno zemljište u privatnom vlasništvu koje se ne održava pogodnim za poljoprivrednu proizvodnju, a vlasnici su nedostupni ili nepoznatog boravišta dade u prisilan zakup. V. kod Josipović, T., Stvari u vlasništvu države i drugih osoba javnog prava (javno vlasništvo), Zbornik Pravnog fakulteta Sveučilišta u Rijeci, vol. 22, br. 1/2001., str. 127-128, bilješka 119.

7 Članak 31. stavak 1. ZZOKD-a predviđa, pak, mogućnost imenovanja privremenog skrbnika nepokretnom kulturnom dobru ako vlasnik ne postupa prema Zakonu, odnosno s dužnom pažnjom, pa kulturnom dobru prijeti opasnost od oštećivanja ili uništenja.

8 Odredba članak 1. Protokola 1. i naslov prema objavljeno prijevodu u NN, MU, br. 6/99, glase: „Zaštita vlasništva, Svaka fizička ili pravna osoba ima pravo na mirno uživanje svojega vlasništva. Nitko se ne smije lišiti svoga vlasništva, osim u javnom interesu, i to samo uz uvjete predviđene zakonom i općim načelima međunarodnoga prava (stavak 1.). Prethodne odredbe, međutim, ni na koji način ne umanjuju pravo države da primijeni zakone koje smatra potrebnima 
slobodne procjene (engl. margin of appreciation) i mogu zahvatiti u ovo pravo, pa ga i ograničiti, ali ograničenje mora biti u skladu s Konvencijom i praksom Europskog suda za ljudska prava (dalje u tekstu: Europski sud ili ESLJP ili Sud). ${ }^{9}$ Zapravo, ,pitanje svih pitanja“ jest je li određeno ograničenje razmjerno, odnosno proporcionalno. U pravnoj teoriji koja proučava Konvenciju među referentnim obilježjima prava na mirno uživanje imovine ${ }^{10}$ izdvaja se nekoliko. Kao prvo, da se u članku 1. Protokola 1. radi o zaštiti prava na mirno uživanje imovine čiji pojam treba razumjeti u konvencijskom značenju, budući da je, kao i niz drugih, plod tumačenja Konvencije posebnim načelima: autonomnog tumačenja pojmova (engl. the autonomous concepts), živućeg instrumenta (engl. living instrument), odnosno evolutivnog tumačenja pojmova (engl. evolutive interpetation), učinkovitosti (engl. doctrine of effectiveness) i u vezi s njim, tzv. pozitivnih obveza država i posljedica po razmjernost, odnosno proporcionalnost ograničenja kada im nije udovoljeno. ${ }^{11}$ Drugo, da Sud slijedi doktrinu, tzv. tri pravila i konkretan slučaj promatra u svijetlu jednog od njih. Znajući da se privremenom upravom ne oduzima pravo vlasništva, niti mijenja njegov sadržaj, već se vlasnika ograničava u izvršavanju vlasničkopravnih ovlasti, privremena uprava ulazi u doseg pravila o, tzv. kontroli korištenja imovine. Sud i kod ovog prava, jednako kao i kod prava na poštovanje doma ${ }^{12}$ provodi, tzv. test (ne)razmjernosti, ${ }^{13}$ no riječ je o različitim testovima. ${ }^{14}$ Važnije razlike tiču se širine polja slobodne procjene koje je kod prava na mirno uživanje imovine šire; sadržaja pojmova javnog, odnosno općeg interesa te pojma nužnosti. ${ }^{15}$ Sličnost postoji u modelu (tehnici) testiranja koja se zove tehnikom, "korak po korak," a sastoji se u tomu što Sud ispitujući je li povrijeđeno zaštićeno pravo kreće od odgovora na prvo pitanje i postavlja sljedeća redom. ${ }^{16}$

da bi uredila upotrebu vlasništva u skladu s općim interesom ili za osiguranje plaćanja poreza ili drugih doprinosa ili kazni (stavak 2.),“

9 V. za načelo supsidijarnosti, kod Marković, S., Trgovac, S., Ustavna tužba i zahtjev Europskom sudu za ljudska prava - analiza i značaj tih pravnih sredstava, Aktualnosti hrvatskog zakonodavstva i pravne prakse, Godišnjak 25., Organizator, Zagreb, 2018., str. 222 et seq.

10 V., npr. Jacobs, F. G., White, R. C. A., Ovey, C., The European Convention on Human Rights, $7^{\text {th }}$ ed, Rainey, B., Wicks, E., Ovey, C., 2017., str. 547 et seq.; Harris, D. J., O’ Boyle, M., Bates, E. P., Buckley, M., Law of the European Convention on Human Rights, $5^{\text {th }}$ ed, Oxford, Oxford University Press, 2014., str. 862 et seq.; Omejec J., Konvencija za zaštitu ljudskih prava i temeljnih sloboda u praksi Europskog suda za ljudska prava, Strasburški acquis, Zagreb, Novi informator, 2013., str. 952 et seq. Gomien, D., Europska konvencija o ljudskim pravima, Zadar, Naklada, 2007., str. 205 et seq.

11 Mihelčić, G., Marochini Zrinski, M., Utjecaj konvencijskih načela tumačenja na pojedine građanskopravne institute (odabrana pitanja), Zbornik radova Pravnog fakulteta u Nišu, br. 78 ., 2018., str. 127-147.

12 Odredba članka 8. stavka 2. Konvencije, prema naprijed navedenom prijevodu, glasi: „Javna vlast se neće miješati u ostvarivanje tog prava, osim u skladu sa zakonom i ako je u demokratskom društvu nužno radi interesa državne sigurnosti, javnog reda i mira, ili gospodarske dobrobiti zemlje, te radi sprječavanja nereda ili zločina, radi zaštite zdravlja ili morala ili radi zaštite prava i sloboda drugih.“

13 Omejec, J., op. cit., str. 990-1003.

14 V. Ivanova i Cherkezov protiv Bugarske, zahtjev br. 46577/15, presuda od 21. travnja 2016.

15 Omejec, J., op. cit., str. 953.

16 Mihelčić, G., Marochini Zrinski, M., Utjecaj zaštite „konvencijskih“ prava na ugovor o najmu 


\section{NACIONALNO URE円ENJE PRIVREMENE UPRAVE (SEKVESTRACIJE)}

\subsection{Općenito}

Naš Ustav proklamira člankom 3., a onda i jamči člankom 48., nepovredivost vlasništva. Kada se kaže vlasništvo, podrazumijeva se razlikovanje pravne ustanove vlasništva (koju Gavella definira kao skup pravnih pravila koja uređuju društvene odnose pripadanja stvari i ostalih imovinskih dobara osobama) i vlasništva kao subjektivnog prava ${ }^{17} \mathrm{u}$ užem i širem smislu (u užem ga smislu, navodi Gavella, treba razumjeti kao jedno od stvarnih prava, a u širem tako što uključuje i ostala stvarna, odnosno imovinska prava). ${ }^{18}$ Ustavno jamstvo vlasništva iz prvog stavka članka 48. Ustava ne znači da se ono ne može ograničiti. Ustavotvorac u drugom stavku ove odredbe kaže da vlasništvo obvezuje te da su njegovi nositelji dužni pridonositi općem dobru. ${ }^{19}$ Ograničenja, međutim, a kako stoji u članku 50. stavku 2. Ustava, trebaju biti predviđena zakonom i služiti zaštiti interesa i sigurnosti države, prirode, ljudskog okoliša i zdravlja ljudi. Gavella ističe da se jamstvom prava vlasništva, osim jamstva pravne ustanove vlasništva, pravnim subjektima jamči da im javna vlast neće zadirati u pravo vlasništva u širem smislu, osim uz pretpostavke predviđene Ustavom tj. da se ne ugrožava sama ustanova vlasništva i da su ograničenja razmjerna (v. članak 16. stavak 2. Ustava). ${ }^{20}$ Posebna zakonska ograničenja mogu biti negativna i pozitivna, a privremena uprava jest posebno pozitivno zakonsko ograničenje. ${ }^{21}$

Ograničenja vlasništva zanimala su i stariju literaturu stvarnog prava. ${ }^{22}$ Stojanović ih je dijelio na ograničenja u užem i u širem smislu. Prva postavlja pravni poredak, a druga proizlaze iz pravnih poslova. Među ograničenja u užem prema autoru, ulaze ona nametnuta privatnim pravom, a ovdje ubraja i susjedska prava te ograničenja zbog javnopravnih zahvata. Potonja, pak, dijeli imajući u vidu učinke

stana, XIII Majsko savetovanje: Uslužno pravo (ur. M. Mićović), Kragujevac, Ministarstvo prosvjete, nauke i tehnološkog razvoja, 2017., str. 968.

17 Prema članku 30. stavku 1. ZV-a, pravo vlasništva se definira kao stvarno pravo na određenoj stvari koje svog nositelja ovlašćuje da s njom i koristima od nje čini što ga je volja te druge od toga isključi, osim protivi li se ovo tuđim pravima ili zakonskim ograničenjima.

18 Gavella, N., u: Gavella, N., Josipović, T., Gliha, I., Belaj, V., Stipković, Z., Stvarno pravo, sv. 1., 2. izd., Zagreb, Narodne novine, 2007., dalje u tekstu: Gavella, N., et al., Stvarno pravo, sv. 1., str. 341-343; Simonetti, P., Vlasništvo i njegove transformacije, jamstvo i zaštita u ustavnom poretku Republike Hrvatske, Zbornik Pravnog fakulteta Sveučilišta u Rijeci, vol. 31, 1. Suppl./2010., str. 355-357; Belaj, V., Klasiček, D., Novije tendencije u ograničavanju prava vlasništva, Pravni vjesnik, vol. 21., 3-4/2005., str 213-216.

19 Perkušić, A., (Ne)usklađenost opće i posebne stvarnopravne normative o stjecanju, vrstama i sadržaju prava služnosti u našem pozitivnom pravu, Zbornik Pravnog fakulteta Sveučilišta u Rijeci, vol. 37., 1/2016., str. 208.

20 Gavella, N., u: Gavella, N., et al., Stvarno pravo, sv. 1., str. 358; Simonetti, P., op. cit., str. 355360.

21 Gavella, N., u: Gavella, N., et al., Stvarno pravo, sv. 1., str. 412.

22 V. Gams, A., Svojina, 2. izd., Beograd, Naučna knjiga, 1988., str. 74-83; Vuković, M., Osnovi Stvarnog prava, Zagreb, Nakladni zavod Hrvatske, 1950., str. 123-140; Stanković, O., Orlić, M., Stvarno pravo, 3. izd., Beograd, Naučna knjiga, 1986., str. 103-119. 
koje polučuju po vlasnika, odnosno traže li od njega kakvo propuštanje, činjenje ili trpljenje. Kada je riječ o činjenju, a koje je zapravo pretpostavka za uspostavu privremene uprave, Stojanović kaže da se od vlasnika traži da sa svojom stvari postupa prema uputi, odnosno onemogućava ga se u slobodnom donošenju odluke hoće li ili ne nešto učiniti. Autor ovim nije završio analizu, budući da je istaknuo i razlikovanje ovisno o tomu je li sadržaj ograničenja u ograničavanju vlasnikova utjecaja na stvar (a ovdje bi ulazila i privremena uprava) ili ovlasti otkloniti utjecaje trećih. Ograničenja, naposljetku, mogu uključiti smanjenje faktičkih ovlasti (koristiti, prerađivati stvar, i sl.) te pravno-poslovnih ovlasti (kada vlasnik ne može pravno raspolagati svojom stvari u određenom opsegu). ${ }^{23}$

\subsection{Pojam i geneza privremene uprave}

Prije negoli se više kaže o postojećem uređenju privremene uprave i pretpostavkama potrebnim za njezino uspostavljanje, treba pojasniti najosnovnije o institutu sekvestracije, a, u biti, odjeliti privremenu upravu od drugih oblika (vrsta) sekvestracije i definirati predmet istraživanja. U najkraćim crtama osvrnut će se na razvoj instituta, a osobito će se naglasiti „,bliska“ veza s uređenjima iz ZV-a te jednim prethodnim uređenjem koje je važno zbog toga što ga je više puta ispitivao Europski sud u povodu zahtjeva za zaštitu prava na mirno uživanje imovine.

2.2.1. O institutu privremene uprave, i općenito o institutu sekvestraciji, danas se puno ne govori. ${ }^{24} \mathrm{U}$ sudskoj praksi još ima predmeta u kojima se odlučuje o zahtjevima za povrat konfiscirane (sekvestrirane) imovine, ${ }^{25}$ no ovim se aspektom,

23 Osvrćući se na intenzitet zahvata ostvarenih zbog ograničenja Stojanović ih uspoređuje s eksproprijacijom i navodi postavke dvije teorije kojima zamjera odsustvo „praktičnosti,“" prvu, koja se temelji na mjeri zahvata u vlasništvo, i drugu, prema kojoj, eksproprijacija ukida bitni element vlasništva (sadržaj), dok se ograničenjima sužava faktična vlast raspolaganja sa stvari, a ne gubi sadržaj prava vlasništva. Autor smatra u praksi korisnijima teoriju pojedinačnog akta, teoriju očekivanja (teoriju žrtve) i teoriju poštovanja privatne koristi kod vlasništva. Prvu (pojedinačnog akta) označava primarno postupovnom, jer se razlika između eksproprijacije i ograničenja sastoji u tomu što su zakonska ograničenja vlasništva uspostavljena zakonom, a kod eksproprijacije je riječ o pojedinačnom aktu. Prema teoriji očekivanja (teoriji žrtve), kao materijalnoj, granica između eksproprijacije za koju se daje naknada i ograničenja vlasništva za koje se ne daje, povlači se prema kriteriju djelovanja zahvata na pogođene osobe, ako su pojedinim vlasnicima nametnuta ograničenja koja za njih predstavljaju posebnu žrtvu, riječ je o eksproprijaciji. Prema trećoj, teoriji poštovanja privatne koristi kod vlasništva najopćenitije se može reći da, neovisno o intenzitetu, vanjske intervencije koje zadiru u vlasništvu, a dokle god omogućuju postizanje određene dobiti, još uvijek se smatraju ograničenjem. Konačno, Stojanović, ukazuje i na bliskost teorije očekivanja s teorijom o smanjivanju supstancije prema kojoj, eksproprijacija postoji kada se zahvatom države povrijedi materijalna supstancija kao bitan sadržaj prava vlasništva tako da ga se u njegovim temeljnim ekonomskim funkcijama ili uništi ili znatno ošteti. Stojanović, D., Stvarno pravo, 5. izd., Beograd, Službeni list SFRJ, 1980., str. 70-76.

24 Detaljno kod Rušnov, A., Šilović, J., Tumač Gradjanskom parbenom postupniku, Zagreb, Knjižara Lav. Hartman (Kugli i Deutsch), str. 366-384.

25 Vrhovni sud Republike Hrvatske, dalje u tekstu: Vrhovni sud ili VS, Rev 2205/11-2 od 9. veljače 2016., VS, Rev 320/05-2 od 21. rujna 2005., US, U-III/926/2007 od 7. svibnja 2009., http://www.iusinfo.hr, stranica posjećena 4. siječnja 2019. 
odnosno vrstom instituta autori neće baviti u ovoj analizi. ${ }^{26}$ Metodologija nalaže da se navede kako je građanskopravna sekvestracija, prema svojim povijesnim izvorima, postojala u obliku ugovorne ili dobrovoljne sekvestracije (sequestratio voluntaria) i sudske sekvestracije (sequestratio necessaria). ${ }^{27}$ Mihelčić, ${ }^{28}$ objašnjava da je, zapravo, rimski depositum in sequestrem pretočen u građanske zakonike 19. stoljeća koje su vrijedili u hrvatskim zemljama. Pozivajući se na literaturu, navodi nadalje, da se sudska sekvestracija dijelila na privremenu (provizornu) i ovršnu sekvestraciju te da je bila uređena u postupovnim propisima, tako da su, najprije, u građanskom postupovnom propisu bile uređene i privremena i ovršna sekvestracija, ${ }^{29}$ a, potom da je ovršnu sekvestraciju uredio ovršni propis. ${ }^{30}$ Nadalje, autorica ističe da je materijalno uporište instituta dolazilo iz temeljnoga materijalnog propisa ${ }^{31}$ koji je određivao da ,ako su parci ili sud predali komu stvar, o kojoj je raspra, da ju čuva čuvar se zove uzapitelj (sekvestar), a prava i obveze uzapitelja prosuđuju se po načelima ovdje ustanovljenim.” Njegov je „nasljednik“ i naš Zakon o obveznim odnosima ${ }^{32}$ koji ostavu uređuje člancima 725. do 743. ZOO-a, ali isključuje njihovu primjenu na nekretnine, ${ }^{33}$ kao što je činio i njegov prethodnik, Zakon o obveznim odnosima iz $1978 .{ }^{34}$ U postojećim uređenjima, i u onom iz Zakona o parničnom postupku ${ }^{35} \mathrm{i}$ u

26 V. članak 10. Zakona o konfiskaciji imovine i o izvršenju konfiskacije, Službeni list, dalje u tekstu: Sl. list, DFJ, br. 40/45, 71/45, 70/45, Sl. list FNRJ, br., 61/46, 105/46 i 47/1951, dalje u tekstu: ZKIIK, koji je određivao da, prema njemu, sekvestracija ima značenje privremenog oduzimanja uprave nad cjelokupnom imovinom ili dijelom imovine osobe za koju je postojala temeljita pretpostavka da će protiv nje biti izrečena konfiskacija i prenošenje uprave na državno tijelo nadležno za upravljanje imovinom u svrhu osiguranja imovinskih interesa države.

27 Rušnov, A., Šilović, J., op. cit., str. 366-369.

28 V. detaljno za genezu instituta kod Mihelčić, G., Ovlaštenje hipotekarnih vjerovnika na namirenje hipotekarne tražbine sekvestracijom nekretnine de lege lata i de lege ferenda, u: Liber Amicorum in honorem dr. sc. Jadranko Crnić (1928.-2008.), Zagreb, Novi Informator, 2009. str. 408 et seq.

29 Privremena (provizorna) sekvestracija bila je uređena §§ 425-437 Građanskog parbenog postupnika od 16. rujna 1852. s novelama, dalje u tekstu: G.p.p., dok su ovršnu sekvestraciju uređivali $\S \S 480-481$. istog propisa.

30 Uređenje ovršne sekvestracije značajnije je izmijenjeno pravilima Zakona o izvršenju i obezbjeđenju od 9. srpnja 1930., dalje u tekstu: ZIO, točnije njegovim pravilima iz $§ \S 79-106$ u kojima je sekvestracija detaljno uređena po uzoru na austrijska i njemačka rješenja (primarno, austrijska). Ovaj propis ujedno je i posljednji koji je uređivao ovršnu sekvestraciju. Što se tiče privremene sekvestracije, ona više nije uređivana, pa ju nije predvidio Zakonik o sudskom postupku u građanskim parnicama od 13. srpnja 1929. Kraljevine Jugoslavije, kao ni propisi koji su uslijedili. V. kod Mihelčić, G., ibidem.

31 V. § 968. Općeg građanskog zakonika od 29. studenog 1852. s kasnijim noveliranjima, dalje u tekstu: O.g.z. Rušnov, A., Šilović, J., op. cit., str. 367.

32 NN, br. br. 35/05, 41/08, 125/11, 78/15 i 29/18, dalje u tekstu: ZOO.

33 Pravila ZOO-a koja uređuju ostavu kažu da njezin objekt mogu biti samo pokretne stvari (članak 725. stavak 2. ZOO-a).

34 Sl. list SFRJ 29/78, 39/85, 46/85, 57/89, NN, br. 53/91, 73/91, 3/94, 111/93, 107/95, 7/96, 91/96, 112/99, 88/01 i 35/05 (dalje u tekstu: ZOO/78).

35 S1. list SFRJ, br. 4/77, 36/77, 36/80, 69/82, 58/84, 74/87, 57/89, 20/90, 35/91, NN, br. 53/91, 91/92, 112/99, 88/01, 117/03, 88/05, 2/07, 84/08, 123/08, 57/11, 148/11 - pročišćeni tekst, 25/13 i 89/14 (dalje u tekstu: ZPP). 
onom iz Ovršnog zakona, ${ }^{36}$ pravila o sekvestraciji nema. Zapravo, navodi Mihelčić, jednako je bilo i prema njihovim prethodnicima. ${ }^{37}$ Međutim, privremena uprava, odnosno sekvestracija koju analiziramo samo bi djelomično imala obilježja građanske sekvestracije, budući da je, kako kaže Gavella, javna vlast ta koja sili vlasnika na poštovanje ograničenja prava vlasništva $i$, nastavlja, da to mora činiti čuvajući vlasništvo, između ostalog, i u duhu prava na mirno uživanje imovine. ${ }^{38}$

U našem pravnom sustavu postoje još neki instituti donekle slični privremenoj upravi koju analiziramo, a riječ je o takva dva instituta, privremenoj mjeri oduzimanja nekretnine i njezina povjeravanja na čuvanje i upravu predlagatelju osiguranja ili trećoj osobi (članak 347. stavak 4. OZ-a) te mjeri osiguranja oduzimanja imovinske koristi ostvarene protupravnom radnjom u kaznenom postupku - oduzimanja nekretnine i njezinog povjeravanja na čuvanje i upravljanje državnom tijelu nadležnom za upravljanje državnom imovinom (članak 557.a stavak 1.a) Zakona o kaznenom postupku ${ }^{39}$ ), no niti oni nisu predmet ovog istraživanja. Razlog tomu nalazi se $u$ drukčijoj svrsi ovih instituta s obzirom na privremenu upravu koja se uspostavlja zbog zaštite zaštićenog dobra kada vlasnik ne učini ono što je od njega traženo.

Za razmjere ovog poglavlja, potrebno je spomenuti i uređenja iz dva (sada derogirana) propisa koja su predviđala uspostavu određenih oblika privremene uprave, a njihova je rješenja već kontrolirao Europski sud ${ }^{40}$ i naši najviši sudovi. ${ }^{41}$ Riječ je o Zakonu o davanju u najam stanova na oslobođenom teritoriju ${ }^{42}$ koji je omogućavao najam stanova na određenom području pod posebnim pretpostavkama (radilo se o stanovima sa specifičnim ,vlasničkim“ režimima, v. članak 1. ZDNSOT-a) te Zakonu o privremenom preuzimanju i upravljanju određenom imovinom ${ }^{43} \mathrm{kojim}_{\mathrm{je}}$,privremeno preuzeta i dana na korištenje, upravljanje i nadzor imovina fizičkih osoba“" (opet, u

36 NN, br. 112/12, 25/13, 93/14, 55/16 i 73/17 (dalje u tekstu: OZ).

37 Mihelčić se osvrće na uređenja iz prijašnjeg Zakona o izvršnom postupku, S1. list SFRJ, 20/78, 6/82, 74/87, 57/89, 20/90, 27/90, 35/91, NN, br. 26/91, 53/91, 91/92, 57/96, dalje u tekstu ZIP/78, te ZPP-a i ranijih građanskih postupovnih propisa. Mihelčić, G., op. cit., str. 417.

38 Gavella, N., u: Gavella, N., et al., Stvarno pravo, sv. 1., str. 415.

$39 \mathrm{NN}$, br. $152 / 08,76 / 09,80 / 11,91 / 12,143 / 12,56 / 13,145 / 13,152 / 14$ i 70/17 (dalje u tekstu: ZKP).

40 Npr. u predmetima: Brezovec protiv Hrvatske, zahtjev br. 13488/07, presuda od 29. ožujka 2011.; Vučak protiv Hrvatske, zahtjev br. 889/06, presuda od 23. listopada 2008.; Radanović protiv Hrvatske, zahtjev br. 9056/02, presuda od 21. prosinca 2006.; Kunić protiv Hrvatske, zahtjev br. 22344/02 presuda od 11. siječnja 2007. i dr.

41 V. općenito o praksi Ustavnog suda, Crnić, I., Ustav Republike Hrvatske u praksi, Organizator, Zagreb, 2018., str. 542-565, 580-591 i dr. Marković, S., Radin, M., Trgovac, S., Ustavna zaštita prava vlasništva u svijetlu stavova Ustavnog suda Republike Hrvatske, Zbornik Pravnog fakulteta Sveučilišta u Rijeci, vol. 32., 1/2011., str. 599-631; Radolović, A., Jamstvo prava vlasništva u praksi Ustavnog suda Republike Hrvatske i Europskog suda za ljudska prava, Aktualnosti hrvatskog zakonodavstva i pravne prakse, Godišnjak 16., Organizator, Zagreb, 2009., str. 1-41. Još, Held, M. Primjena Europske konvencije za zaštitu ljudskih prava i temeljnih sloboda u praksi Ustavnog suda Republike Hrvatske, Hrvatska i komparativna javna uprava, vol. 16., 3/2016., str. 527-551.

42 NN, br. 73/95 i 101/98 (dalje u tekstu: ZDNSOT).

43 NN, br., 73/95, 7/96 i 101/98 (dalje u tekstu: ZPPUOI). V. i tzv. Program povratka i zbrinjavanja prognanika, izbjeglica i raseljenih osoba NN, br. 92/98 i 88/02 (dalje u tekstu: ZDNSOT). 
jednom specifičnom režimu i pod posebnim pretpostavkama, v. članak 1. i 2. ZPPUOI -a). ${ }^{44} \mathrm{U}$ praksi koja je uz njih kreirana, u biti, se radilo o provjeri pojedinih rješenja s obzirom na to povrjeđuju li ustavno jamstvo vlasništva, odnosno konvencijsko pravo na mirno uživanje imovine. U odlukama koje su donesene uočavaju se detalji zaštite koja im je pružena. Ustavni sud u odluci U-III-1122/2013 od 4. studenoga 2014. dao je za pravo podnositelju i zaštitio njegovo povrijeđeno pravo te naglasio što smatra relevantnim. Pritom se ističe sljedeće: zahtjev da se imovina, odnosno njezin pojam u ustavnopravnom smislu autonomno koncipira, ${ }^{45}$ zahtjev da se konkretan slučaj analizira kroz tri pravila i odredi na koje se od njih odnosi povreda ${ }^{46}$ te zahtjev da miješanje države, odnosno uvođenje ograničenja bude predviđeno zakonom, legitimno i da se ne zahvaća u zaštićeno pravo, tako da se naruši pravična ravnoteža (engl. fair balance) između općeg interesa i interesa pojedinca i potonjeg pretjerano optereti, ${ }^{47}$ odnosno, da se ostvari zahtjev da ograničenje, pa i ono privremenom upravom bude

44 Gavella citira odluku Županijskog suda u Rijeci, Gž-1540/97 od 4. ožujka 1998, u kojoj je rečeno da se radilo o ,zakonskom gubitku i zakonskom preuzimanju posjeda stvari (imovine) koje su nakon toga dane na privremenu upravu i korištenje." Gavella, N., u: Gavella, N., et al., Stvarno pravo, sv. 1., str. 176, bilješka 51. V., npr. članke 3. ZDNSOT-a i 5. ZPPUOI-a.

45 Naime, najprije je naglašeno da se pravo vlasništva u smislu članka 48. stavka 1. Ustava shvaća u autonomnom ustavnom značenju (op. aut.) te kazano da ga je potrebno vrlo široko tumačiti, budući da „obuhvaća, načelno, sva imovinska prava“, te se u tom pravcu navode odgovarajuće „odluke U-III-661/1999 od 13. ožujka 2000.; U-III-72/1995 od 11. travnja 2000., U-III-551/1999 od 25. svibnja 2000., U-III-476/2000 od 14. lipnja 2000. U-IIIB-1373/2009 od 7. srpnja 2009.,“, §33.

46 U ovom je smislu Ustavni sud podsjetio „,na odluku U-IIIB-1373/2009 od 7. srpnja 2009., NN, br. 88/09, u kojoj je podrobno obrazložio ustavni okvir zaštite imovinskih prava u Republici Hrvatskoj utvrđujući da Ustav poznaje tri pravila o vlasništvu koja korespondiraju s istim takvim pravilima izgrađenima u praksi ESLJP-a kad je riječ o članku 1. Protokola 1.“.

47 Zatim se ističe: „Da bi ograničenje prava vlasništva bilo opravdano pod uvjetima iz članka 50. stavka 2. Ustava i članka 1. stavka 2. Protokola 1., dostatno je da bude ispunjen zahtjev iz tih odredaba i da nadležna državna tijela postignu pravednu ravnotežu između interesa države i pogođenog vlasnika,“§ 33.2 . 
razmjerno (proporcionalno). ${ }^{48,49}$

2.2.2. Osim u članku 32. ZV-a, privremena uprava pojavljuje se u još nekim pravilima iz ZV-a. Riječ je o uređenjima: ${ }^{50}$ kada plodouživatelj ugrožava sućanstvo stvari na kojoj ima plodouživanje i kod prisilnog namirenja založnog vjerovnika. Tako, ako je ugroženo sućanstvo poslužne stvari njezin vlasnik može zahtijevati da mu plodouživatelja dade primjereno osiguranje (članak 209. stavak 1. ZV-a). Ne učini li to, sud može ukinuti plodouživanje i obvezati vlasnika da plodouživatelju plati naknadu (članak 209. stavak 2. i članak 242. stavak 3. ZV-a). Međutim, smatra li to boljim rješenjem i na zahtjev plodouživatelja koji se obvezao snositi troškove uprave i uporabe i korištenja poslužne stvari, može i postaviti upravitelja njome (članak 209.

48 U kojem bi smislu treba razmišljati pri utvrđenju o (ne)razmjernosti Vrhovni sud rekao je, npr. u odluci Rev 1000/10-2 od 9. travnja 2013. U njoj je najprije označen što je u konkretnom slučaju bio legitimni cilj miješanja ,zaštita napuštene imovine od propadanja i devastacije i ujedno rješavanje stambenog pitanja osoba koje su bile raseljene ili su ostale bez domova uslijed rata.“ Istaknuto je da je u trenutku podnošenje zahtjeva na povrat nekretnine „legitimni cilj prestao postojati u dijelu zaštite imovine od propadanja i devastacije, a ostao je samo (njegov dio - op. aut.) tj. interes države da stambeno zbrine osobe kojima je kuća dana na privremeno korištenje.“ Stoga je, „zadržavajući kuću tužitelja pod privremenom upravom i nakon podnošenja zahtjeva za povrat te imovine, tuženica ograničila vlasničko pravo tužitelja isključivo radi ispunjena svoje obveze zbrinjavanja naseljenika na području posebne državne skrbi.“ Pitanje pravične ravnoteže i (ne)razmjernosti obrazloženo je, npr. i u odluci VS, Rev x 1283/2015-2 od 29. lipnja 2016. u kojoj stoji: „Tužiteljici nije bilo oduzeto pravo vlasništtva, već je bila ograničena u pravu korištenja tim vlasništvom. Zbog toga predmet spora može biti pitanje je li tuženik odgovoran za prekomjerno ograničenje prava vlasništva tužiteljice, a koje se ogleda u nemogućnosti posjedovanja nekretnine ... Prema pravnom shvaćanju ovog suda u konkretnom slučaju, s obzirom da je tužiteljici praktički kuća vraćena u posjed bez odgode nakon što je stavila zahtjev za njenim vraćanjem nije narušena ravnoteža između općeg interesa i zaštite prava pojedinca.“ Dostupno na: http://www.iusinfo.hr, mrežna stranica posjećena 21. siječnja 2019.

49 U ovom kompleksu važnije pitanje bilo je ono o naknadi, za koju je Ustavni sud u odluci U-III/5229/2014 od 13. travnja 2017. zaključio da vlasnicima privremeno preuzetih nekretnina „pripada pravo na naknadu zbog nemogućnosti korištenja obiteljske kuće, i to od dana podnošenja zahtjeva za njezino vraćanje u posjed (v. U-III-195/2006 od 18. lipnja 2008., NN, br. 78/08 i U-III-1192/2005 od 25. rujna 2008., NN, br. 123/08).“ S tim što „ovisi o okolnostima konkretnog slučaja i ocjeni suda je li vlasnicima zbog duljine razdoblja u kome su bili onemogućeni u posjedu svoje obiteljske kuće (razdoblje od podnošenja zahtjeva za vraćanje do ponovnog stupanja u posjed), nametnut prekomjeran teret $u$ odnosu na legitimni cilj zbog kojeg je ona dana na korištenje privremenim korisnicima.“ V. da je „Vrhovni sud zauzeo pravno shvaćanje o pripadanju naknade vlasniku od podnošenja zahtjeva do vraćanja nekretnine u posjed na sjednici Građanskog odjela Vrhovnog suda (1/09) održanoj 2. ožujka 2009., Ing. SP 2009., 4, 6, 1, str. 85.," cit. prema: Žuvela, M., Vlasničkopravni odnosi, Zakon o vlasništvu i drugim stvarnim pravima, Zakon o zemljišnim knjigama, Zagreb, Organizator, 2014., str. 99.

50 Postoji i specifičan slučaj kada su suvlasnici propustili međusuvlasničkim ugovorom urediti međusobne odnose glede stvari. Naime, suvlasnici su bili dužni zaključiti međuvlasnički ugovor u vezi sa zajedničkim dijelovima i ugovor s upraviteljem u roku od dvanaest mjeseci od dana stupanja na snagu ZV-a (članak 384. ZV-a). Ako nisu osigurali upravljanje nekretninom u tom roku, jedinice lokalne samouprave mogle su odrediti fizičku ili pravnu osobu koja bi obavljala poslove uprave tom nekretninom (prinudnog upravitelja) sa svim ovlastima inače predviđenim za upravitelja nekretnine kojemu su suvlasnici ugovorom povjerili upravljanje (članak 385. ZV-a). 
stavak 3. i članak 242. stavak 4. ZV-a). Drugi slučaj je onaj kada založni vjerovnik u zalogu ima stvar ili pravo koje je sposobno dati plodove ili druge koristi iz čije se vrijednosti može namiriti založna tražbina. U tom je slučaju ovlašten tražiti da sud uspostavi privremenu upravu zalogom i postavi upravitelja koji će ubirati plodove, odnosno koristi i unovčavati ih, te dobivene iznose polagati u sud radi namirenja iz pologa (članak 336. stavak 7. ZV). Za razliku od privremene uprave uređene člankom 32. ZV-a, u potonjim slučajevima privremenu upravu određuje sud koja nije predmet daljnje analize.

2.2.3. S obzirom na to i u kontekstu općeg pravila iz članka 32. ZV-a koje uređuje privremenu upravu, a neovisno o razlikama, treba spomenuti i slučaj iz članka 111. $\mathrm{ZV}-\mathrm{a}$, u kojem se privremena uprava ne spominje, ali se u literaturi u vezi sa slučajem koje ovo pravilo uređuje ne smatra nezamislivom. Prančićs navodi da bi bilo moguće, kada postoji ozbiljna opasnost da se nečija zgrada ili njezin dio potpuno ili djelomično sruši zbog čega prijeti opasnost susjednoj nekretnini i kada se od vlasnika može zahtijevati da poduzme sve potrebne mjere da bi se spriječio nastanak štete (naravno, ako ih ne poduzme), uspostaviti privremenu upravu. Zamisao o privremenoj upravi nad ruševnom zgradom čiji su vlasnici odsutni i nepoznatog boravišta, zapravo, iznosi Sarvan ${ }^{52}$ i detaljno analizira na koji način ovo učiniti, a očito je da i Prančić dijeli ovo mišljenje kada (citirajući Sarvan) navodi da bi se „privremena uprava uspostavila radi određivanja popravaka ili rekonstrukcije, odnosno uklanjanja ruševne zgrade ako popravak ili rekonstrukcija nije moguća, zbog opasnosti koja prijeti za život i zdravlje ljudi ili susjednih nekretnina, odnosno radi zaštite drugih opravdanih interesa". ${ }^{53}$

\subsection{Pretpostavke i obilježja privremene uprave}

\subsubsection{Općenito ${ }^{54}$}

Privremena uprava jest posebno zakonsko ograničenje prava vlasništva, pa je

51 Prančić, V., Opasnost od rušenja zgrade, Zbornik Pravnog fakulteta Sveučilišta u Rijeci, vol. 31, 2/2010., str. 873-874.

52 Sarvan, D., Postupanje sa zgradama od kojih prijeti opasnost od nastanka štete, Informator, 2001., br. 4986., str. 8-9 i 13.

53 Sarvan, D., op. cit., str. 8; Prančić, V., op. cit., str. 874. Usp. ciljeve navedene u članku 27. stavku 1. ZGI-a kojim se građevinskog inspektora ovlašćuje da u provedbi inspekcijskog nadzora naloži vlasniku građevine otklanjanje oštećenja zbog kojih postoji opasnost za život ljudi, okoliš, druge građevine ili stabilnost tla na okolnom zemljištu.

54 U kontekstu uvodno naglašene mogućnosti pristupa Sudu te u povodu sudske kontrole općenito Stažnik, između ostalog, citira odlomak iz predmeta Bistrović protiv Hrvatske, zahtjev br. 25774/05, presuda od 31. svibnja 2007. (radilo se o izvlaštenju) u kojem se kaže da: ,pravo na pošteno suđenje u kontekstu upravnih akata podrazumijeva da zakonom ustanovljen neovisni i nepristrani sud, u inicijalnom odlučivanju ili odlučivanju povodom žalbe, mora imati punu nadležnost, odnosno mogućnost ispitivanja činjenica i prava koji se odnose na spor pred njim kako bi udovoljio uvjetima članka 6. Konvencije“. Stažnik, op. cit., str. 129. V. za urbanu komasaciju, Tuhtan Grgić, I., Ograničenja prava vlasništva u postupku urbane komasacije, Zbornik Pravnog fakulteta Sveučilišta u Rijeci, vol. 32., 1/2011., str. 644. V. za sudsku kontrolu općenito. Branković, G., Sudska praksa i upravni spor, doktorski rad, Univerzitet u Nišu, Pravni fakultet, Banja luka, 2012., str. 29 et seq. 
prva pretpostavka njezina uspostavljanja da je riječ o slučaju predviđenom zakonom. Dopušteno ju je uspostaviti ne učini li vlasnik ono što je bio dužan i to je sljedeća pretpostavka. Nadalje, traži se da je riječ o zaštiti interesa i sigurnosti države, prirode, spomenika kulture, ljudskog okoliša ili zdravlja ljudi. Vlasnika se, kao što sam naziv instituta kaže, samo privremeno može ograničiti u izvršavanju njegovih vlasničkopravnih ovlasti.

Prema članku 32. stavku 3. ZV-a, privremenu upravu uspostavlja općinski načelnik,,$^{55}$ gradonačelnik, odnosno župan. ${ }^{56} \mathrm{U}$ predmetnoj odredbi nije ništa rečeno o aktu kojim se privremena uprava uspostavlja. ${ }^{57}$ Privremena uprava određuje se i provodi odgovarajućom primjenom pravila o privremenom skrbništvu nad ostavinom koja se nalaze u članku 128. Zakona o nasljeđivanju, ${ }^{58}$ ako posebni zakon ne određuje što drugo. Ovaj članak kaže da, kada su nasljednici nepoznati ili nepoznatoga boravišta, sud ostavini postavlja privremenog skrbnik. Sud, međutim, nije uključen u uspostavu privremene uprave. Privremeni skrbnik ostavine ovlašten je, prema članku 128. stavku 1 . ZN-a, u ime nasljednika tužiti i biti tužen, naplatiti tražbinu ili isplatiti dug i uopće zastupati nasljednike, a mogu mu se odrediti i druge, posebne ovlasti i dužnosti (članak 128. stavak 2. ZN-a). Ako bi ovo vrijedilo i za privremenog upravitelja i on bi u općem režimu imao navedene ovlasti i dužnosti. Nadalje, postoji i uputa iz petog stavka članka 128 . ZN-a koji predviđa primjenu nekih pravila predviđenih za izvršitelja oporuke. ${ }^{59}$ Radi se o pravilu iz članku 62. ZN-a. Prema njegovom prvom stavku, izvršitelj oporuke dužan je položiti sudu račun o svom radu i odgovora za štetu koju je skrivio. Ima pravo na naknadu prouzročenih troškova i primjerenu nagradu. Isplaćuje ih se na temelju odluke suda na teret ostavine pazeći da se ne umanji nužni nasljedni dio (članak 62. stavak 2. ZN-a). I privremeni bi upravitelj, zahvaljujući ovim pravilima, trebao (onom tko ga je postavio) položiti račun o svom radu, odgovarao za štetu koju je skrivio i imao pravo na naknadu troškova te primjerenu nagradu. Neke su od ovih dužnosti i ovlasti predviđene u posebnim propisima, a neke se ne spominju. ${ }^{60} \mathrm{U}$ stavku 4., članka $128 . \mathrm{ZN}$-a predviđeno je da sud o postavljanju

55 U jednom trenutku Zakonom o izmjenama i dopunama Zakona o vlasništvu i drugim stvarnim pravima iz 2009., NN, br. 38/09, izmijenjeno je ovlašteno tijelo za uspostavu privremene uprave, pa je umjesto poglavarstvu jedinice lokalne samouprave i jedinice područne (regionalne) samouprave ova ovlast dana općinskom načelniku, gradonačelniku i županu.

56 Seršić, V., Nakić, J., Upravljanje dobrima u vlasništvu jedinica lokalne samouprave, Zbornik Pravnog fakulteta Sveučilišta u Rijeci, vol. 34., 1/2013., str. 580.

57 Npr. prava i obveze privremenog skrbnika utvrđuju se rješenjem o imenovanju (članak 31. stavak 3. ZZOKD-a).

58 NN, br. 48/03, 163/03, 35/05, 127/13 i 33/15 (dalje u tekstu: ZN).

59 Odredbe o izvršitelju oporuke nalaze se u člancima 60. do 63. ZN-a (članak 60. uređuje određivanje izvršitelja oporuke; članak 61. njegove dužnosti; članak 62. spomenuto polaganje računa i nagradu izvršitelju te članak 63., opoziv izvršitelja oporuke). Članak 128. stavak 5. $\mathrm{ZN-a}$ upućuje odgovarajuće primijeniti pravila o izvršitelju oporuke samo za pitanje polaganja računa i nagrade privremenog skrbnika, zapravo, samo na članak 62 . ZN-a.

60 Privremeni skrbnik dužan je za račun i na trošak vlasnika poduzimati mjere zaštite i očuvanja kulturnoga dobra koje mu odredi nadležno tijelo (članak 31. stavak 4. ZZOKD-a); ima pravo na naknadu za rad te troškove provedenih mjera zaštite o čemu rješenjem odlučuje onaj tko ga je imenovao. Dužnost podmirenja nagrade i troškova skrbnika je na vlasniku (članak 31. stavak 5. ZZOKD-a). 
privremenog skrbnika obavijesti tijelo nadležno za skrbništvo (centar za socijalnu skrb) koji prema skrbniku ima jednake ovlasti kao kada ga on postavlja. ${ }^{61}$ Skrbništvo uređuju članci 218. do 280. Obiteljskog zakona ${ }^{62}$ (tzv. posebno skrbništvo, članci 240. do 246. ObZ-a). Prema članku 241. ObZ-a, zbog zaštite pojedinih osobnih i imovinskih prava i interesa, centar može imenovati posebnog skrbnika i osobi kojoj nije poznato boravište najmanje tri mjeseca ili nije dostupna, a nema punomoćnika radi li se o stvarima u kojima se odlučuje prema ObZ-u, iznimno, i u slučaju privremene spriječenosti ili nesposobnosti osobe za obavljanje jednokratnih neodgodivih radnji čije je poduzimanje potrebno radi zaštite njezinih prava i interesa. ${ }^{63,64}$

\subsubsection{Zahtjev da je vlasnik uskratio traženo činjenje u pogledu nekretnine}

Da bi se uspostavila privremena uprava potrebno je da je od vlasnika traženo određeno činjenje u vezi sa stvari (nekretninom), pa da on ovo nije učinio, a da je činjenje koje je od vlasnika traženo u vezi s nekim zakonom predviđenim razlogom. Prva je pretpostavka za uspostavu privremene uprave, dakle, da vlasnik nije učinio ono što je od njega traženo. Dakle, da je izostalo traženo činjenje. Po svemu sudeći, (ne)činjenje ima značenje objektivne pretpostavke, budući da je dovoljno da je izostalo, a ne gledaju se razlozi koji su do ovog doveli. Naime i prema članku 32. ZV-a tako i prema posebnim propisima, uvijek se jednako može uspostaviti privremena uprava, odnosno privremeno skrbništvo. ZPZ tako, u članku 14. stavku 1. predviđa da se poljoprivredno zemljište u privatnom vlasništvu koje se ne održava pogodnim za poljoprivrednu proizvodnju, a vlasnici su nedostupni ili nepoznatog boravišta može dati u zakup. Prema rješenju iz ZZOKD-a, uspostavljanje privremene skrbi na kulturnom dobru moguće je: i kada vlasnik nije učini ono što je trebao za zaštitu

61 U prijašnjem Obiteljskom zakonu iz 2003., NN, br. 116/03, 17/04, 136/04, 107/07, 57/11, 61/21, 25/13, 75/14, 5/15 i 103/15 (dalje u tekstu: ObZ/03), skrbništvo su uređivali članci 149. do 205., a ono za posebne slučajeve, članci 167. do 173. Tzv. posebnog skrbnika, centar je radi zaštite pojedinih osobnih i imovinskih prava i interesa mogao imenovati osobi kojoj najmanje tri mjeseca nije poznato boravište ili nije bila dostupna, a nije imala punomoćnika, odnosno u drugim slučajevima kad je to bilo potrebno radi zaštite prava i interesa neke osobe (članak 168. $\mathrm{ObZ} / 03)$.

62 NN, br. 103/15, dalje u tekstu: ObZ.

63 Ovo je uređenje nešto drukčije od onog iz članka 168. ObZ/03 (v. bilješku 58.). Prema drugom stavku članka 241. ObZ-a, posebni skrbnik treba imati određene posebne kvalifikacije i može se raditi: ili o osobi koja ima položeni pravosudni ispit i zaposlena je u centru za posebno skrbništvo (v. članak 544. et seq. OBZ-a) ili o osobi određenoj javnobilježničkom ispravom (tzv. anticipiranom naredbom), v. članak 236. stavak 6. ObZ-a.

64 Usp. s prijašnjim uređenjem o tzv. posebnom skrbniku, npr. s člankom 171. ObZ/03 kojim se predviđala mogućnost njegova imenovanja osobi kojoj je najmanje tri mjeseca bilo nepoznato boravište ili nije bila dostupna, a nije imala punomoćnika, a što je sud mogao sam učiniti u postupku koji je vodio i o tomu obavijestiti centar za socijalnu skrb. Poseban se skrbnik sada može biti imenovan djetetu (članak 240. ObZ), punoljetnoj osobi (članak 241. ObZ), a nedostupnim osobama ili onima koje su nepoznatog boravišta imenuje se privremeni zastupnik (članak 244. ObZ) ako joj je ono nepoznato najmanje tri mjeseca ili nije dostupna, a nema punomoćnika u postupcima koji su pokrenuti i vode se pred sudom ili javnopravnim tijelima, osim ako joj je imenovan posebni skrbnik. 
kulturnog dobra (članak 31. stavku 1. ZZOKD-a), i kada ga je privremeno napustio, a prijeti opasnost da bude oštećeno ili uništeno (članak 32. stavak 1. ZZOKD-a). Pritom je predmnijeva o privremenom napuštanju vezana uz saznanje o vlasnikovu boravištu. ${ }^{65}$ I Zakonom o obnovi spomeničke cjeline Dubrovnika i drugih nepokretnih kulturnih dobara u okolici Dubrovnika ${ }^{66}$ predviđene su obje varijante: i da će se vlasniku koji je odsutan i ne zna mu se boravište, a nema zastupnika, ili je nepoznat postaviti privremeni skrbnik (članak 16. stavak 6. ZOSCDDNKDOD), i da će, kada vlasnik ne pristupi obnovi građevine Zavod pristupiti izvođenju radova, što, implicira prethodnu uspostavu privremene skrbi.

U kontekstu ove pretpostavke treba kazati da je Ustavni sud u jednoj svojoj odluci, a riječ je o odluci U-I-763/2009 i dr. od 30. ožujka $2011 .{ }^{67}$ u kojoj se raspravljalo o prisilnom zakupu poljoprivrednog zemljišta i kojom je ukinut članak 15. (i 16. i dr.) Zakona o poljoprivrednom zemljištu iz $2008 .{ }^{68}$ u dijelu u kojem se od vlasnika tražilo da poljoprivredno zemljište obrađuje sukladno agrotehničkim mjerama, zauzeo stajalište kako one „moraju biti primjerene činjeničnim okolnostima i razmjerne cilju koji se želi postići, a k tome, u ostvarenju legitimnog cilja trebaju u što većoj mjeri omogućiti i održati privatnu upotrebljivost vlasništva." U tom je smislu, naglašen zahtjev da se „uključi i uvažavanje gospodarskih mogućnosti onih na koje se dotične mjere imaju primijeniti,“ a, u biti, je Ustavni sud sugerirao da u slučaju ,kada vlasnik to ne može, prisilno davanje u zakup nije mjera koja odgovara načelu razmjernosti, jer lišava vlasnika privatne upotrebljivosti njegova vlasništva, a da ZPZ/08-e istodobno ne predviđa nikakve druge mjere za postizanje istog legitimnog cilja koje bi prethodile mjeri prisilnog zakupa, a kojima bi se manje zadiralo u prava vlasnika poljoprivrednog zemljišta." S druge strane, već sada treba spomenuti predmet Matas u kojem je podnositelju pružena zaštita prava na mirno uživanje imovine, a radilo se o ograničenju njegova prava na nekretnini kulturnom dobru, a za razmjere rasprave o ovoj pretpostavci zanimljiv je zbog svojevrsnog putokaza koji je dao Europski sud kada je naveo: ,iako se ne dovodi u pitanje kako procjena vrijednosti nekog objekta kao kulturnog dobra može zahtijevati kompleksne i dugotrajne procjene i studije“ (čime je opravdavana primjena mjere preventivne zaštite u razdoblju od šest godina) nije prihvatljiv ,jedini razlog koji je Konzervatorski odjel naveo - nemogućnost da od Općinskog suda... ishodi izvadak iz zemljišnih knjiga u odnosu na zgradu... imajući

65 Postoje zakonske predmnjeve o, tzv. privremenom i trajnom napuštanju kulturnog dobra. O prvom se slučaju radi ako je vlasnikovo boravište nepoznato, a nema ovlaštenog zastupnika, te ga nadležno tijelo nije u mogućnosti obavijestiti o njegovim obvezama u roku od šest mjeseci od dana pokušaja prve dostave pismena (članak 32. stavak 2. ZZOKD-a). Smatra se da je vlasnik trajno napustio kulturno dobro ako je njegovo boravište nepoznato, a nema ovlaštenog zastupnika, te svoje obveze ne izvršava deset godina od dana donošenja rješenja o skrbništvu (članak 32. stavak 3. i 4. ZZOKD-a). Ono u tom slučaju (kada ga je trajno napustio vlasnik) postaje vlasništvo Republike Hrvatske. V. kod Ernst, H., Poljanec, K., Stvarnopravna i carinskopravna zaštita kulturnih dobara u svjetlu europske antiterorističke politike, Zbornik Pravnog fakulteta Sveučilišta u Rijeci, vol. 38., br. 1/2017., str. 201.

$66 \mathrm{NN}$, br. 21/86, 33/89, 26/93, 29/94, 128/99, 19/14, 32/14 i 99/14, dalje u tekstu: ZOSCDDNKDOD.

67 NN, br. 39/11.

68 NN, br. 152/08, 25/09, 153/09, 21/10, 90/10, 39/11, 63/11 i 39/13, dalje u tekstu: ZPZ/08. 
u vidu da su podaci iz zemljišnih knjiga javni, lako dostupni drugim sredstvima, uključujući putem interneta, te da ništa ne ukazuje na to da je Konzervatorski odjel poduzeo ozbiljan pokušaj da ishodi te informacije te da je u tome bio neuspješan" “. ${ }^{\circ}$

\subsubsection{Zahtjev da se radi o zaštiti zakonom predviđenog dobra/interesa}

Da bi se uspostavila privremena uprava na nekretnini mora se raditi o zaštiti nekog od zakonom taksativno navedenih dobara, odnosno interesa: ${ }^{70}$ interesa $\mathrm{i}$ sigurnost države, prirode, ljudskog okoliša i zdravlja ljudi te kulturnih dobara (članak 32. stavak 3. ZV-a). Privremena uprava, naime, uspostavlja se upravo zbog zaštite određenog dobra, odnosno interesa koji je ugrožen ili postoji ozbiljna opasnost da će biti ugrožen. Ovo vrlo jasno proizlazi iz citirane odredbe $Z \mathrm{~V}$-a, ali i iz posebnih pravila. Tako, članak 14. stavak 1. ZPZ-a predviđa da će se poljoprivredno zemljište u privatnom vlasništvu koje se ne održava pogodnim za poljoprivrednu proizvodnju (v. članak 4. ZPZ-a) dati u zakup, ali, što se nastavno kaže, kada je ovo potrebno zbog zaštite tla, okoliša ili ljudi. Prema članku 27. stavku 1. ZZOKD-a, vlasništvo na kulturnom dobru moguće je ograničiti zbog zaštite i očuvanja kulturnoga dobra, odnosno prijeti li opasnost od njegova oštećivanja ili uništenja (članak 31. stavak 1. ZZOKD-a). ZOSCDDNKDOD-om je predviđena dužnost (i pravo) vlasnika, ovlaštenika prava i drugih imatelja građevina unutar spomeničke cjeline da ih se obnovi (članak 15. stavak 2. ZOSCDDNKDOD-a). Svrha obnove, pa sljedstveno i to o kojem se zaštićenom dobru radi (i kao predmetu privremene skrbi, i cijelog Zakona) vidi se već iz prvog članka. Njime je određeno da se radi osiguranja posebnih uvjeta za trajno očuvanje i obnovu povijesno-kulturnih dobara staroga dubrovačkog grada i otklanjanja štetnih uzroka koji ugrožavaju njegove vrijednosti kao i radi otklanjanja posljedica potresa i zaštite od potresa, stari dubrovački grad, sa svim povijesnim dijelovima, proglašava, kao povijesno-kulturno dobro, spomeničkom cjelinom (pa ovim dovodi i u poseban režim).

\subsubsection{Privremena narav privremene uprave}

Temeljno obilježje privremene uprave jest njezino privremeno trajanje. Osim što treba privremeno trajati, privremena uprava treba trajati i najkraće moguće imajući u vidu razloge zbog kojih je uspostavljena. Već je rečeno kako je Europski sud u predmetu Matas nerazmjernima ocijenio mjere preventivne zaštite kulturnog dobra u trajanju od šest godina (v. dio 2.3.2) i apostrofirao, istina, u nešto drukčijem kontekstu, da „načelo dobrog upravljanja zahtijeva u slučajevima kada je predmet spora pitanje

69 Matas, § 41-42.

70 Staničić je u kontekstu izvlaštenja analizirao na koji način Europski sud shvaća opći interes, odnosno odgovara na pitanje kada izvlaštenje smatra provedenim u općem interesu. U svom je radu naveo i odgovarajuću praksu te proveo istraživanje razlika između 'općeg interesa,' 'javnog interesa' i 'interesa Republike Hrvatske' u hrvatskom ustavnopravnom kontekstu. Staničić, F., Razlikovanje javnog interesa, općeg interesa i interesa Republike Hrvatske u kontekstu javnopravnih ograničenja prava vlasništva, Zbornik radova Pravnog fakulteta $u$ Splitu, 1/2018., str. 112-126. Za praksu, o tomu da Ustav ne poznaje opći interes, već interes Republike Hrvatske, Crnić, I., op. cit., str. 582. 
od općeg interesa, pogotovo ako ono utječe na temeljna ljudska prava poput onih povezanih s vlasništvom, da javna tijela djeluje na vrijeme te na prikladan i prije svega dosljedan način." ${ }^{\text {"71 }}$

Pravilo iz članka 32. stavka 5. ZV-a predviđa da se nekretnina na kojoj je uspostavljena privremena uprava može dati u zakup i pritom ne određujući ništa o tomu koliko zakup može (najdulje) trajati. Predviđeno je, međutim, da vlasnik može tražiti da se stvar dana u zakup vrati i prije njegova isteka, ispuni li obvezu zbog koje je uspostavljena privremena uprava (članak 32. stavak 7. ZV-a). S obzirom na trajanje privremene uprave, određena razlika može postojati kada je riječ o slučaju u kojem je svrha zakupa da se ostvarenom zakupninom namiri tražbina povezana s razlogom uspostavljanja privremene uprave od onih s drugom zaštitnom svrhom. Najdulje vrijeme do kojeg, prema ZPZ-u, zakup može trajati jest deset godina, s tim što vlasnik može pet godina nakon uvođenja zakupnika u posjed, tražiti da mu se zemljište dano u zakup preda u posjed (članak 15. stavak 9. ZPZ-a). Da se, ipak, razmišlja u kategoriji privremenosti vidljivo je iz zabrane da se poljoprivredno zemljište koristi za podizanje trajnih nasada i izgradnju građevina u svrhu poljoprivredne proizvodnje (članak 14. stavak 5. ZPZ-a). Prema prijašnjim rješenjima, npr. iz članka 12. et seq. Zakona o poljoprivrednom zemljištu iz $1991 .{ }^{72}$ rok je iznosio tri godine, kao i prema članku 10. et seq. Zakona o poljoprivrednom zemljištu iz $2001 .^{73}$ te članku 15. et seq. ZPZ/08-a (prije negoli je derogiran spominjanom odlukom Ustavnog suda).

\subsubsection{Ograničavanje izvršavanja vlasničkopravnih ovlasti}

Uspostavom privremene uprave na nekretnini ne mijenja se sadržaj prava vlasništva, ${ }^{74}$ već se vlasnika ograničava u izvršavanju njegovih vlasničkopravnih ovlasti dok privremena uprava traje. Vidjet će se poslije da je jedno od ključnih pitanja konvencijske zaštite upravo u vezi s opsegom ograničenja. Više se puta spomenulo da je sekvestriranu nekretninu moguće dati u zakup. ${ }^{75}$ Zakupom prestaje vlasnikova faktična vlast (jasno, ako je postojala), a uspostavlja se zakupnikova koji postaje neposredni posjednik. Ovim se ne dira u samostalnost vlasnikova posjeda, budući da je zakupnik neposredni, ali samo nesamostalni posjednik. ${ }^{76}$ Prema ZV-u, a što je također

71 Matas, $\S 43$.

72 NN, br. 34/91, 71/91, 40/92, 26/93, 79/93, 90/93, 29/94, 37/94, 65/94, 21/95, 48/95, 19/98, 105/99 i 66/01 (dalje u tekstu: ZPZ/91).

73 NN, br. 66/01, 87/02, 48/05, 90/05 i 152/08, dalje u tekstu: ZPZ/01.

74 Gavella, N., u: Gavella, N., et al., Stvarno pravo, sv. 1., str. 414.

75 Korisno je spomenuti postojanje članka 393. ZV-a, prema kojem se za ugovore o zakupu zaključene po članku 32. ZV-a ,ne primjenjuju odredbe Zakona o zakupu poslovnoga prostora“" u povodu kojeg je Sarvan navela da bi se zakup mogao uspostaviti neposrednom pogodbom, ali je to bilo puno prije novih posebnih rješenja. Sarvan, D., op. cit., str. 8.

76 Kada je riječ o izvršavanju faktične vlasti na stvari, može se spomenuti posjed onog čijim je zahvatom sekvestrirana nekretnina dan u zakup, ali će njegov posjed, najčešće, biti samo idealan Gavella je u jednom drugom kontekstu baveći se uređenjima iz propisa koji više nisu na snazi, a ticali su se privremenog upravljanja određenom imovinom i njezina povjeravanja, promatrao idealni posjed koji je nastajao zbog primjene tih. Gavella, N., u: Gavella, N., et al., Stvarno pravo, sv. 1., str. 176, bilješka 51. 
spomenuto, vlasnik može tražiti da mu se nekretnina vrati prije isteka zakupa, a sličnu ovlast predviđa i ZPZ-e. I ovim je uređenjem predviđeno da vlasnik ima pravo da mu se zakupljeno zemljište vrati prije isteka zakupa, ali uz posebnu pretpostavku koja se u ZV-u ne predviđa. ZPZ, naime, određuje da se povrat ne može tražiti prije negoli prođe pet godina od uvođenja zakupnika u posjed (članak 15. stavak 9. ZPZ-a). ${ }^{77}$

Opća pravila ne govore ništa o visini zakupnine, već samo određuju njezinu namjenu. Što se tiče posebnih režima, oni detaljnije uređuju neke segmente zakupa, a kao važniji (u konvencijskom smislu) onaj o naknadi, odnosno visini zakupnine. U pravilima ZPZ-a predviđeno je da se poljoprivredno zemljište daje u zakup po zakupnini čiji je početni iznos određen Zakonom (v. članak 37. ZPZ). ${ }^{78}$ Sredstva koja se ostvare od zakupa (umanjena za određene troškove) ${ }^{79}$ pripadaju vlasniku zemljišta (članak 15. stavak 1. ZPZ-a) i on, u svakom trenutku, može zatražiti njihovu isplatu. ${ }^{80}$

Privremena uprava na nekretnini, načelno, ne utječe na mogućnost vlasnika da raspolaže nekretninom u smislu da bi mu bilo zabranjeno da ju otuđi ili založi. $\mathrm{S}$ tim da se privremena uprava pojavljuje kao određena vrsta tereta na nekretnini. $\mathrm{Za}$ otuđenje nekretnine (stvari) u pojedinim posebnim uređenjima postoje pravila kojima je u korist određenih osoba i tijela ustanovljeno pravo prvokupa (npr. članak 36. et seq. ZZOKD-a o prvokupu kulturnog dobra). Međutim, ona se primjenjuju neovisno je li na kulturnom dobru uspostavljena privremena skrb, dakle i kada jest $\mathrm{i}$ kada nije. Postojanje prava prvokupa ne utječe na ovlast vlasnika da otuđi kulturno dobro u smislu da mu priječi otuđenje, već traži da se otuđenje provede poštujući ovo pravo. Postoje, primjerice, i pravila koja se tiču stjecanju prava vlasništva na poljoprivrednom zemljištu od strane određenih osoba, pa u ovom smislu i ograničenja vezana za otuđenja, ${ }^{81}$ no njima se ne uspostavlja nekakav drukčiji režim koji bi bio u vezi s činjenicom privremenog upravljanja poljoprivrednog zemljišta. Zakup se može evidentirati u zemljišnoj knjizi, što će, sukladno članku 88. stavku 1. OZ-a, utjecati na ovršnu perspektivu zakupnika. Nešto je drukčije s privremenom upravom i zaštitom trećega (stjecatelja, založnog vjerovnika) u povodu njezine vidljivosti iz zemljišne

77 Važnija obveza zakupnika je da zemljište o vlastitom trošku iskrči u roku od dvije godine od dana uvođenja u posjed (članak 15. stavak 7. ZZP-a) i nastavi ga koristiti u poljoprivredne svrhe. U suprotnom, ugovor o zakupu se raskida i zakupnik je dužan platiti zakupninu za sve ugovoreno vrijeme trajanja zakupa (članak 15. stavak 8. ZZP-a).

78 Ugovor o zakupu, u dijelu koji se odnosi na zakupninu i predaju u posjed, mora biti sklopljen kao ovršna isprava, određuje se da ugovor koji nije sklopljen u pisanom obliku nema pravni učinak (članak 38. stavci 2. i 5. ZPZ-a). Njegova daljnja posebnost je što prava i obveze iz ugovora teku od dana uvođenja u posjed (članak 39. stavak 3. ZPZ-a). Sadržaj ugovora uređuje članak 42. ZPZ-a, a prava i obveze stranaka više odredbi, npr. članak 43., odnosno 50. ZPZ-a (o usklađivanju zakupnine). Za raskid ugovora, izvan onog uređenog pravilima ZPZ-a, predviđena je primjena, "općih propisa obveznog prava", članak 47. ZPZ-a.

79 V. članak 15. stavak 3. ZZP-a.

80 Vlasniku zemljišta koji ne zatraži isplatu uplaćenih sredstava na ime zakupnine u roku od deset godina od dana uvođenja u posjed takva ovlast prestaje i tzv. izdvojena sredstva raspoređuju se onako kako određuje članak 49. stavak 1. ZPZ-a (članak 15. stavak 10. ZPZ-a).

$81 \mathrm{Na}$ njemu pravo vlasništva ne mogu stjecati strane pravne i fizičke osobe, osim ako međunarodnim ugovorom i posebnim propisom nije drukčije određeno (članak 2. stavak 2. ZPZ-a). 
knjige (koliko god ona bila privremena ili manje privremena). ${ }^{82}$ Stjecatelj koji bi stekao nekretninu na kojoj je uspostavljena privremena uprava stječe ju opterećenu ovim režimom, budući da uspostava privremene uprave na nekretnini svoje učinke, a zapravo, ograničenje ostvaruje prema svakodobnom vlasniku nekretnine. Ako takva mogućnost postoji, stjecatelj bi se mogao osloboditi privremene uprave učini li ono što je prethodno od vlasnika traženo, a on nije učinio i zbog čega je ona i uspostavljena.

Privremeno skrbništvo nad nepokretnim kulturnim dobrom uspostavlja se kada nadležno tijelo utvrdi da vlasnik s njim ne postupa prema Zakonu, odnosno s dužnom pažnjom, a prijeti mu opasnost od oštećivanja ili uništenja. ${ }^{83}$ Zanimljivost ovog uređenja postoji s obzirom na rješenje o osiguranju tražbine troškova i nagrade privremenog skrbnika zakonskim založnim pravom. Naime, njih je privremenom skrbniku dužan podmiriti vlasniku (članak 31. stavak 5. ZZOKD-a). Ako ovo ne učini, namiruje ih se iz proračuna odgovarajuće jedinice lokalne samouprave u čiju se korist na kulturnom dobru osniva zakonsko založno pravo (članak 31. stavak 6. ZZOKDa) ${ }^{84}$ Prije je rečeno da se skrbništvo na kulturnom dobru može uspostaviti i kada ga je vlasnik privremeno napustio (a to je i u slučaju vlasnikova nepoznatog boravišta), a prijeti opasnost od njegova oštećivanja ili uništenja. Ovlasti čelnika jednake su kao i u naprijed navedenom slučaju, pa vrijedi sve što je rečeno. Privremeno skrbništvo nad nepokretnim kulturnim dobrom uređeno je i u ZOSCDDNKDOD-u čije odredbe (članci 15. do 42.) uređuju prava i obveze vlasnika i drugih imatelja građevina (i Zavoda) u obnovi spomeničke cjeline grada Dubrovnika. Zakon predviđa supsidijarnu primjenu ZZOKD-a, ${ }^{85}$ no sadržava i neka posebna rješenja. U članku 16. stavku 1. ZOSCDDNKDOD-a uređeno je pravo, odnosno obveza (dužnost) vlasnika građevine unutar spomeničke cjeline da ju obnovi kada se to predvidi godišnjim programom obnove. ${ }^{86}$ Vlasnik ima pravo na obnovu na cjelini koja se sastoji od više zgrada (bloka zgrada), a koje vlasnik dijela bloka nije u mogućnosti izvesti izdvojeno (članak 16.

82 U članku 87. Zakona o zemljišnim knjigama, NN, br. 91/96, 68/98, 137/99, 114/01, 100/04, 107/07, 152/08, 126/10, 55/13, 60/13 i 108/17, dalje u tekstu: ZZK predviđena je mogućnost zabilježbe imenovanja ili opoziva upravitelja. Međutim, njegov stavak 4. govori o zabilježbi prisilne uprave i upravitelja koji se dopušta na temelju ovršne odluke kojom je uspostavljena na prijedlog zainteresirane osobe s učinkom da se prisilna uprava može provesti protiv svakoga koji kasnije stekne zemljište. Usp. da je Sarvan predlagala u izreci rješenja o privremenoj upravi naložiti, "zabilježbu da je za nekretninu uspostavljeno privremeno upravljanje zgradom". Sarvan D., op. cit., str. 8 i 13.

83 U tom slučaju gradonačelnik Grada Zagreba, gradonačelnik ili općinski načelnik na čijem se području nalazi kulturno dobro imenuje privremenog skrbnika na prijedlog nadležnog tijela (članak 31. stavak 1. ZZOKD-a). On to može predložiti (imenovanje privremenog skrbnika) i u slučaju ostavinskog ili drugog postupka čiji je predmet kulturno dobro (članak 31. stavak 2. ZZOKD-a).

84 Skrbništvo prestaje donošenjem rješenja, koje se donosi na prijedlog nadležnog tijela kada prestanu razlozi radi kojih je bilo uvedeno (članak 31. stavak 7. ZZOKD-a).

85 Zakon određuje da se na prava i obveze vlasnika te ovlaštenika prava i drugog imatelja građevine unutar spomeničke cjeline primjenjuju odredbe ZZOKD-a, ZV-a, propisi iz područja prostornog uređenja i gradnje te drugi propisi.

86 Zavod je dužan obavijestiti vlasnike građevina koje su predviđene za obnovu godišnjim programom. Obavijest se izdaje putem sredstava javnog priopćavanja, oglasne ploče Zavoda te putem mrežnih stranica Zavoda (članak 16. stavak 2. ZOSCDDNKDOD-a). 
stavak 3. ZOSCDDNKDOD-a) ${ }^{87}$ Nasuprot, na građevini (zgradi) kao cjelini, vlasnik građevine, pak, ima dužnost obnoviti građevinu. Ne pristupi li obnovi, odnosno ne obavijesti li Zavod o namjeri radova u roku od tri mjeseca od objave godišnjeg programa obnove, Zavod može pristupiti izvođenju radova (članak 16. stavak 5. ZOSCDDNKDOD-a). S tim da je, a na što posebno treba obratiti pažnju, predviđeno da „vlasniku, koji je odsutan i ne zna mu se boravište“ (i nema ovlaštenog zastupnika ili je nepoznat), nadležno tijelo iz ZZOKD-a, ,na prijedlog Zavoda postaviti će privremenog skrbnika“" (članak 16. stavak 6. ZOSCDDNKDOD-a). Stipulaciju odredbe o ,privremenom skrbništvu vlasniku,“ po našem sudu, ipak, treba shvatiti kao „privremeno skrbništvo na nekretnini,“ jer bi ovo bilo usklađeno sa ZZOKD-om na koji se i upućuje. Posebno pravilo predviđa da je u slučaju otuđenja građevine u koju su uložena sredstva Zavoda, a stjecatelj nije vlasnikov nasljednik prvoga nasljednog reda, vlasnik dužan prije otuđenja ta sredstva vratiti (članak 21. stavak 1. ZOSCDDNKDOD-a). ${ }^{88} \mathrm{~S}$ tim da za osiguranje njihove naplate Zavod stječe zakonsko založno pravo u trajanja od 15 godina i dužan ga je upisati u zemljišne knjige (članak 21. stavak 2. ZOSCDDNKDOD-a).

\section{KOEGZISTENCIJA PRIVREMENE UPRAVE (SEKVESTRACIJE) I PRAVA NA MIRNO UŽIVANJE IMOVINE}

U ovom dijelu rada promatraju se obilježja zaštite prava na mirno uživanje imovine analizom predmeta u kojima se uočava paralela s uređenjem privremene uprave, odnosno skrbništva.

\subsection{Autonomna koncepcija imovine i njezina konvencijska zaštita}

Prvo pitanje pri ispitivanju postoji li povreda prava na mirno uživanje imovine jest ulazi li konkretan predmet u doseg članka 1. Protokola 1. Pojam imovine Sud tumači dajući mu konvencijsko značenje. ${ }^{89} \mathrm{U}$ tom se smislu razumije i pravo vlasništva, ${ }^{90} \mathrm{a}$,

87 Za pripremu i izvođenje radova vlasnik građevine dužan je Zavodu omogućiti poduzimanje svih potrebnih aktivnosti obnove (izradu tehničke i druge dokumentacije, provođenje pripremnih istražnih radova i obnovu građevine, članak 16. stavak 4. ZOSCDDNKDOD-a).

88 Usp. npr. da se u članku 9. stavku 2. Pravilnika o korištenju sredstava spomeničke rente, Službeni glasnik Grada Zagreba, br. 6/11 i 13/17, predviđa mogućnost da se iz sredstava spomeničke rente namire naknade za rad privremenog skrbnika s troškovima provedenih mjera zaštite kulturnog dobra.

89 Ovo je svojevrsna konstanta koja "raste," a od prije je primijećena u literature. Gavella, N., Jamstvo vlasništva iz članka 1. Prvog protokola uz Europsku konvenciju za zaštitu ljudskih prava i temeljnih sloboda, u: Gavella, N., Alinčić, M., Hrabar, D., Gliha, I., Josipović, T., Korać, A., Baretić, M., Nikšić, S.: Europsko privatno pravo, (ur. D. Hrabar), Pravni fakultet u Zagrebu, Zagreb, 2002., dalje u tekstu: Gavella, N., et al., Europsko privatno pravo, str. 43 et seq., posebno v.: II Predmet i sadržaj jamstva vlasništva iz članka 1. prvog Protokola (točke A. i B.), str. 46-55. Crnić Grotić, V., Zaštita prava vlasništva u međunarodnom pravu, Zbornik Pravnog fakulteta Sveučilišta u Rijeci, vol. 22., 1/2001. str. 364 et seq.

90 Sermet, objašnjavajući zaštitu pruženu člankom 1. Protokola 1. kaže da ne polazi od tradicionalno shvaćenog prava vlasništva i njegove zaštite (premda ju uključuje) i da upotrijebljene termine treba razumijeti u konvencijskom značenju. Sermet, L., The European Convention on Human 
u biti, i sam pojam imovine ako se shvati u značenju skupa subjektivnih imovinskih prava predstavljenih jednim nositeljem. ${ }^{91} \mathrm{U}$ novijoj se literaturi sve se više spominju i korekcije konvencijske koncepcije te uočavaju trendovi sužavanja i proširenja pojma imovine. “92

Zaštita koju Sud pruža pravu iz članka 1. Protokola 1. pod svoj je „kišobranom“ uključila niz, zapravo, objekata zaštite (kao tipičnih, npr. tzv. postojeću (engl. existing possessions) pokretnu i nepokretnu imovinu), ${ }^{93}$ a najvažnije je da podnositelj može tvrditi da je došlo do povrede članka 1. Protokola 1. samo ako se pobijane odluke

Rights and property rights, 2. pon. izd., Vijeće Europe, Strasbourg, 1999., str. 11-19, dostupno na: https://www.echr.coe.int/LibraryDocs/DG2/HRFILES/DG2-EN-HRFILES-11(1998).pdf, mrežna stranica posjećena 12. siječnja 2109. Ovdje će se spomenuti jedan predmet kojim se, inače, ilustrira treće pravilo o kontroli korištenja imovine, a upravo kako bi se pokazao detalj o konvencijskom shvaćanju pojma imovine. Riječ je o predmetu Gasus Dosier i Fördertechnik GmbH protiv Nizozemske, zahtjev br. 15375/89, presuda od 23. veljače 1995., u kojem se Sud suočio sa situacijom da su nizozemske vlasti zbog namirenja porezne tražbine zaplijenile od kupca stvar na kojoj je prodavatelj pridržao pravo vlasništva do isplate kupovnine u cijelosti. Izraženo je stajalište: ,kako nema razlike uživa li podnositelj zahtjeva u odnosu na stvar ovlasti s naslova prava vlasništva ili pridržaja prava vlasništva, budući da je neovisno došlo do miješanja u pravo na mirno uživanje imovine," Gasus Dosier i Fördertechnik GmbH, § 53. Ne treba izgubiti iz vida i utjecaje koji su na konvencijsko pravo ostvaren iz anglosaksonskog pravnog kruga u kojem je, primjerice, pravo vlasništva na nekretnini sličnije zakupu onako kako se shvaća u pravnim sustavima kontinentalnog pravnog kruga. V. detaljnije kod Komnenić, D., Pravo na mirno uživanje imovine u presudama i odlukama Europskog suda za ljudska prava donijetim u postupcima u kojima su bivše jugoslavenske republike bile odgovorne države, doktorski rad, Beograd 2017., str. 33-44. Dostupno na: http://union.edu.rs/wp-content/uploads/2017/05/ Doktorska-distrtacija-Du\%C5\%A1 anka-Komneni\%C4\%87.pdf, mrežna stranica posjećena 22. siječnja 2019.

91 Klarić, P., Vedriš, M., Građansko pravo, Zagreb, Narodne novine, 2003., str. 93. V. i Gamsovu koncepciju imovine „kao skupa potraživanja i obveza iz obveznopravnih odnosa, dakle kao tzv. aktivu i pasivu,“ za koju autor ističe da je tako moguće „razlikovanje imovine kao skupa prava i obveza od imovinske mase kao predmeta th prava i obveza," (što je i njegov prigovor prethodnoj definiciji). Gams, A., op. cit., str. 76.

92 Beširević, V., Popović, D., Leskoviku, M., Marinković, T., Studija o primjeni prakse Europskog suda za ljudska prava u upravnim sporovima (ur. V. Beširević), Danilovgrad, Regionalna škola za javnu upravu (ReSPA), 2018. str. 123-126.

93 Omejec, pa zatim i Kontrec i Boić zaključuju da, prema postojećoj praksi Suda, u imovinu ulaze: „ekonomski interesi iz poslovanja društva (Tre Traktorer Aktiebolag protiv Švedske, zahtjev br. 10873/84, presuda od 7. srpnja 1989., H. protiv Belgije, zahtjev br. 8950/80, presuda od 30. studenog 1987.), dionice i poslovni udjeli (Bramelid i Malmstrom protiv Švedske, zahtjevi br. 8588/79, 8589/79, odluka od 12. listopada 1982.), intelektualno vlasništvo (Anheuser-Busch Inc. protiv Portugala, zahtjev br. 73049/01, presuda od 11. siječnja 2001.), potraživanja (Stran Greek Refineries i Stratis Andreadis protiv Grčke, zahtjev br. 13427/87, presuda od 9. prosinca 1994.) i dugovi (Almeida Garrett, Mascarenhas Falcao i drugi protiv Portugala, zahtjevi br. 29813/96, 30229/96, presuda od 11. siječnja 2000.), ugovorna prava (De Napoles Pacheco protiv Belgije, zahtjev br. 7775/77, odluka od 5. listopada 1978.,), budući prihodi (AnheuserBusch Inc.), legitimna očekivanja (Kopecky protiv Slovačke, zahtjev br. 44912/98, presuda od 28. rujna 2004.) te pravo na mirovinu i druga socijalna prava ad personam (engl. social security benefits)." Cit. prema: Kontrec, D., Boić, V., Konvencija za zaštitu ljudskih prava i temeljnih sloboda i praksa ESLJP - građanskopravni aspekti, Priručnik za voditelje/voditeljice, Pravosudna akademija, 2017., str. 38-39., Omejec, J., op. cit., str. 957. 
odnose na njegovu imovinu u smislu ove odredbe. Pojam imovine ima, ne jednom je ponovljeno, autonomno značenje koje je neovisno o značenju u domaćem pravu. Vezano uz naprijed spomenute objekte zaštite, može se dati nekoliko primjera koji se detaljnije vide, u tzv. Praktičnom vodiču kroz uvjete dopuštenosti. ${ }^{94}$ Sažeto, jezikom Suda, navodi se sljedeće: da se „članak 1. Protokola 1. primjenjuje samo na postojeće vlasništvo, odnosno da se ne jamči pravo na stjecanje vlasništva", ${ }^{5}$ da se ,imovinom može smatrati i vlasnički interes sadržan u prirodi tražbine ako ima dovoljnu osnovu u nacionalnom pravu" ${ }^{96}$ kao i ,dug utvrđen presudom (ako je dovoljno određen da bude ovršiv)" ${ }^{97}$ dok „,budući prihod predstavlja 'imovinu' samo ako je zarađen ili ako postoji ovršiv zahtjev u odnosu na njega", ${ }^{98}$ da se ,članak 1. Protokola 1. primjenjuje na intelektualno vlasništvo kao takvo", ${ }^{99}$ dok se ,udio u trgovačkom društvu također može smatrati vlasništvom”, ${ }^{100}$ kao i „naknade socijalnog osiguranja." ${ }^{101}$

U predmetu Gaćeša protiv Hrvatske ${ }^{102}$ naglašeno je kako „,... vlasništvo može biti 'postojeće vlasništvo' ili 'imovina' uključujući potraživanja za koja podnositelj može tvrditi da ima barem 'legitimno očekivanje' (koje mora biti konkretnije naravi od same „nade“) tj. da će se ostvariti „djelotvorno“ uživanje prava vlasništva.“103

Bezulaženja u detalje vidljivo je kakoje najspornije pitanje legitimnih očekivanja. Nekoliko se predmeta smatra važnim upravo za tu konvencijsku dimenziju imovine, kao npr. predmet Kopecký. ${ }^{104} \mathrm{U}$ bitnom, u imovinu se uključuju: ,postojeća imovina ili aktiva u koju ulaze... i tzv. legitimna očekivanja da će se ostvariti učinkovito uživanje nekog imovinskog prava,“ ali „,ne i takvog koje prethodno nije stečeno „kao ni onog koje je bilo „uvjetovano ako se zakonski uvjet izjalovio,“ Kopecký, § 35 .

94 Vijeće Europe, Strasbourg, 2014., https:/gov.hr/UserDocsImages//Moja\%20uprava// Prakti\%C4\%8Dn i\%20vodi\%C4\%8D\%20kroz\%20uvjete\%20dopu\%C5\%A1 tenosti.pdf., mrežna stranica posjećena 12. veljače 2019.

95 Slivenko i drugi protiv Latvije [VV], zahtjev br. 48321/99, odluka od 9. listopada 2003., § 121 i Kopecký, § 35 (b).

96 Npr. u slučaju „kada postoji ustanovljena sudska praksa domaćih sudova koja to potvrđuje,” v. Plechanow protiv Poljske, zahtjev br. 22279/04, presuda od 7. srpnja 2009., §83.

97 Burdov protiv Rusije [VV], zahtjev br. 54522/00, presuda od 3. travnja 2012., § 90.

98 Anheuser-Busch Inc. § 64.

99 Ibidem, $\S 72$.

100 Olczak protiv Poljske, zahtjev br. 30417/96, odluka od 7. studenog 2002., §60.

101 Ukoliko država ugovornica u svom zakonodavstvu ,predviđa pravo na isplatu neke naknade socijalne skrbi,“ Stec i drugi protiv Ujedinjenog Kraljevstva [VV], zahtjevi br. 65731/01 i 65900/01, odluka od 6. srpnja 2005., §§ 53-55.

102 Zahtjev br. 43389/02, odluka od 1. travnja 2008., str. 7.

103 Isto je naglašeno i u odluci Velikog vijeća u predmetu Gratzinger i Gratzingerova protiv Češke, zahtjev br. 39794/98, odluka od 10 srpnja 2002., gdje je Sud rekao „Vjerovanje da će zakon koji je na snazi biti izmijenjen u korist podnositelja ne može se smatrati oblikom 'legitimnog očekivanja' u smislu članka 1. Protokola 1. Sud smatra da postoji razlika između puke nade u restituciju, koliko god razumljiva ta nada može biti, i legitimnog očekivanja, koje mora biti mnogo konkretnije naravi od puke nade i (mora) biti utemeljeno na zakonskoj odredbi ili pravnom aktu kao što je sudska odluka“, $\S \S 73-74$.

104 V. i predmet Prince Hans-Adam II of Liechtenstein protiv Njemačke, zahtjev br. 42527/98, presuda od 12. srpnja 2001. i Gratzinger i Gratzingerova. 
Da bi legitimno očekivanje ${ }^{105}$ bilo konvencijski relevantno treba biti ,potkrijepljeno (vezano) tzv. vlasničkim interesom.“ Odnosno, ,imati uporište u nacionalnom pravu kao, npr. kada postoji odgovarajuća sudska praksa ili je dovoljno utvrđeno da ga je moguće izvršiti.“"106, 107 U predmetu Matas te predmetu Valette $i$ Doherier protiv Francuske, ${ }^{108}$ Sud je kazao da se radi o „mjerama kontrole korištenja vlasništva podnositelja“, a u predmetu Kristiana Ltd. protiv Litve, ${ }^{109} \mathrm{u}$ fokusu su bila i legitimna očekivana podnositelja koja su se, u različitim varijantama, sastojala u namjeri ostvarenja određenog poslovnog cilja koji je kolidirao s općim interesom.

\subsection{Miješanje drăave u pravo na mirno uživanje imovine}

Daljnje pitanje tiče se samog miješanja države u pravo na mirno uživanje imovine. U pravilu je odgovor potvrdan, pa se nerijetko činjenica miješanja niti ne osporava, kao što je slučaj u predmetu Matas gdje Sud elaborira da „nakon što je sama Vlada priznala da je došlo do miješanja ne vidi nikakav razlog da presudi drugačije“, § 32. Činjenica miješanja samog po sebi nije problem. Kao što je još uvodno rečeno, države kod ovog prava imaju široko polje slobodne procjene i mogu u njega ulaziti. Ilustrativno se navodi u predmetu Matas kako „ograničenje prava podnositelja zahtjeva na mirno uživanje njegovog vlasništva primjenom mjere preventivne zaštite nije otvoreno za kritiku per se, pogotovo uzimajući u obzir legitimni cilj kojem se težilo te široku slobodu procjene koju država ima kada je riječ o pitanjima kulturnih dobara“ $\S 40 .{ }^{110}$ Miješanje treba biti predviđeno zakonom, odnosno mora postojati „,pravna

105 Rečeno je: „postoji razlika između puke nade u restituciju, koliko god razumna da nada bila, i legitimnog očekivanja, koje mora biti konkretnije naravi od puke nade i mora imati uporište u zakonskoj odredbi ili pravnom aktu poput npr. sudske odluke," Gratzinger i Gratzingerova, $\S 69$, v. Kopecký, § 35. V i recentne hrvatske predmete, Bikić protiv Hrvatske, zahtjev br. 50101/12, presuda od 29. svibnja 2018., §§ 45-46 i Radomilja i drugi protiv Hrvatske, zahtjevi br. 37685/10, 22768/12, presuda od 20. ožujka 2018., § 143. Evo što se kaže u predmetu Bikić: ,'Vlasništvo' može predstavljati 'postojeće vlasništvo' ili potraživanja koja su dovoljno utvrđena da se mogu smatrati 'imovinom' ... (ali - op. aut.) samo ako postoji dostatna osnova za taj interes u nacionalnom pravu (na primjer, kada postoji dosljedna sudska praksa domaćih sudova koja to potvrđuju), odnosno kada je zahtjev dovoljno utvrđen da bi bio izvršiv ... Sud se također pozivao na tužbene zahtjeve za koje podnositelj zahtjeva može tvrditi da ima barem 'legitimno očekivanje' da će se ostvariti, odnosno da će dobiti učinkovito uživanje prava vlasništva. Međutim, legitimno očekivanje nema neovisno postojanje; mora biti povezano s vlasničkim interesom za koji postoji dostatna pravna osnova u nacionalnom pravu“. Bikić, ibidem.

106 Kopecký, §§ 45-52.

107 U predmetu Radomilja uskraćena je zaštita pravu na mirno uživanje imovine, budući da je ocjenjeno kako predmet na ulazi u njegov doseg. „Pitanje koje je trebalo ispitati jest jesu li zahtjevi podnositelja da budu utvrđeni vlasnicima predmetnih zemljišta, isključujući razdoblje od 6. travnja 1941. do 8. listopada 1991. godine na koje su se podnositelji pokušali prekasno pozvati pred Velikim vijećem, (ipak) imali dovoljno uporište u nacionalnom pravu da se smatraju 'imovinom' i stoga 'vlasništvom' zaštićenim člankom 1. Protokola 1.“, Radomilja, § 144.

108 Zahtjev br. 6054/10, presuda od 29. studenog 2011., § 17.

109 Zahtjev br. 36184/13, presuda od 6. veljače 2018. §§ 104-105.

110 V. predmet SCEA Ferme de Fresnoy protiv Francuske zahtjev br. 61093/00, odluka od 1. 
osnova za miješanje” i ,težiti cilju koji je u općem interesu” (kako je, npr. rečeno u predmetu Statileo protiv Hrvatske $\left.{ }^{111}\right) .{ }^{112} \mathrm{O}$ potrebi da ograničenje bude zakonito gotovo da ne treba posebno govoriti, no ipak, imajući u vidu da će se ograničenje zbog privremene uprave promatrati u okviru kontrole nad korištenjem imovine, može se spomenutu da je baš u predmetima iz ove skupine naglašeno kako kontrola mora imati svoje opravdanje u nacionalnom pravu, ali i u pravu Europske unije (v. predmet Hava Yolları Turizm ve Ticaret Anonim Şirketi protiv Irske ${ }^{113}$ ), a Sud, određenu mjeru kontrole može ispitati i u svjetlu međunarodnog prava (poput konvencija UN-a ili Vijeća Europe, v. predmet Gogitidze i drugi protiv Gruzije $\left.{ }^{114}\right)$.

Ograničavanje izvršavanja vlasničkopravnih ovlasti uspostavom privremene uprave, odnosno privremenim skrbništvom, poslužimo li se jezikom Suda „nije otvoreno za kritiku per se, pogotovo uzimajući u obzir legitimni cilj“. Tako, i naš Ustavni sud promatrajući u svojoj, prije navedenoj odluci, prisilni zakup poljoprivrednog zemljišta u svjetlu općeg uređenja ističe da se ,pravni institut prisilnog davanja u zakup poljoprivrednog zemljišta u privatnom vlasništvu može smatrati u suglasnosti s Ustavom". ${ }^{115}$ Ograničenje samo po sebi ne mora biti ustavno ili konvencijski neprihvatljivo, ako je udovoljeno i drugim zahtjevima. Carss-Frisk objašnjava da stavak 2., članka 1. Protokola određuje da prethodne odredbe (misli na stavak 1.) ni na koji način ne umanjuju pravo države da primijeni zakone koje smatra potrebnima kako bi „uredila upotrebu vlasništva u skladu s općim interesom ili za osiguranje plaćanja poreza ili drugih doprinosa ili kazni““. ${ }^{116}$ Od dva opravdana razloga miješanja države u pravo na mirno uživanje vlasništva kod privremene uprave, odnosno privremenog skrbništva radilo bi se o prvom, „da je miješanje u skladu s općim interesom.“"117 Već smo spomenuli rad u kojem je Staničić analizirao u kojem

prosinca 2005., prema: Matas $\S 40$.

111 Zahtjev br. 12027/10, presuda od 10. srpnja 2014., §§119-145. Elijaš, D., Marković, S., Trgovac, S., Povreda konvencijskog prava na mirno uživanje vlasništva, Zbornik Pravnog fakulteta Sveučilišta u Rijeci, vol. 36, 1/2015., str. 251 et seq.

112 Određena pitanja ovim su se povodom pojavila u predmetima koji su kod nas dobro poznati i koje upravo zbog toga nismo detaljnije analizirali, kao npr. u cijelom setu onih čijim se rodočelnikom može označiti predmet Statileo te onih vezanih za, sada, derogirana uređenja privremenog upravljanja određenim nekretninama u (sub)specijaliziranim režimima, kao Radanović, Kunić, Vučak, i niz drugih (koja su, u biti, obuhvaćena kada su u dijelu rada 2.2.2 iznesena stajališta Ustavnog i Vrhovnog suda o potrebi zaštite prava na mirno uživanje imovine na strani njihovih podnositelja), no i u njime se najreferentnijom ne može smatrati činjenica koja se tiče legitimiteta miješanja, ali mogu i jesu druga pitanja.

113 Zahtjev br. 45036/98, presuda od 30. lipnja 2005.

114 Zahtjev br. 36862/05, presuda od 12. svibnja 2015.

115 Ističe $\mathrm{i}$ da je $\mathrm{u}$ tom smislu, ,institut prisilnog davanja u zakup, propisan ZPZ/08-om, samo poseban izraz općeg instituta davanja u zakup stvari od interesa za Republiku Hrvatsku u situaciji kad je vlasnik te stvari na temelju zakona dužan u odnosu na nju nešto poduzeti, a njega se na to ne može prisiliti“.

116 Carss-Frisk, M., The right to property: A guide to the implementation of article 1 of protocol No. 1 to the European Convention on Human Rights, Human rights handbooks br. 4. Strasbourg, Vijeće Europe, 2001., str. 26 et seq, https://rm.coe.int, stranica posjećena 20. studenoga 2018.

117 Usporedbe radi u odluci U-I-1559/2007 od 21. veljače 2007. izraženo je o jednoj drugoj mjeri sljedeće stajalište: „Ustavni sud na kraju napominje da je zakonodavac ovlašten propisati 
smislu Sud shvaća opći interes i odgovara na pitanje kada smatra da je (izvlaštenje) provedeno $u$ općem interesu. ${ }^{118}$ Nakon što je usporedio ovu koncepciju s našim uređenjem (općeg, javnog i interesa Republike Hrvatske), autor smatra da Europski sud ne slijedi naše uređenje ${ }^{119}$ pa ,, kada bi mogla postojati razlika između koncepta 'javnog interesa' $i$ 'općeg interesa' u članku 1. Protokola 1. (prvom pravilu), u pitanju o kojem se ovdje radi ne može se povući nikakva fundamentalna razlika“, i zaključuje, da „Europski sud u osnovi smatra da između ova dva izraza nema supstancijalne razlike". ${ }^{120}$ Posegne li se ponovo za ilustracijom u predmet Matas ovo se može i „plastično“ vidjeti, jer se u njemu kaže: "Sud je već presudio da se očuvanjem kulturnih dobara $\mathrm{i}$, ondje gdje je primjereno, njihovom održivom uporabom, teži legitimnom cilju održavanja određene kvalitete života, očuvanja povijesnih, kulturnih i umjetničkih korijena neke regije i njezinog stanovništva, te su oni kao takvi temeljna vrijednost čija su zaštita i promidžba dužnost javnih tijela“. ${ }^{121}$ Vrlo slično stajalište izraženo je i u predmetu Kristiana Ltd. u kojem je podnositelju uskraćena zaštita prava na mirno uživanje imovine, ali i kazano da se država umiješalo u ovo pravo iz naprijed navedenih pobuda ( $\S 1104-105)$. Ono što je korisno naglasiti jest da miješanje države u općem interesu u smislu stavka 2., članka 1. Protokola ne treba promatrati kroz prizmu, u našem članku 32 . ZV-a navedenih interesa i sigurnosti države, prirode, spomenika kulture, ljudskoga okoliša ili zdravlja ljudi, u funkciji legitimnih ciljeva, već kao posebno ustanovljene konvencijske uzročne veze sa zaštićenim interesom. ${ }^{122}$ Višekratno spominjani predmet Matas, te predmeti Potomska i Potomski protiv Poljske, ${ }^{123}$ Valette i Doherier ( $(16)$, Kristiana Ltd. neki su od onih u kojima se radilo o ograničenjima zbog različitih mjera poduzetih zbog zaštite (kulturnih, arheoloških i dr. dobara) i sve su one podvrgnute provjeri eventualne povrede prava na mirno uživanje imovine, kroz treće pravilo, dakle s obzirom na kontrolu korištenja imovine o čemu će više riječi biti u sljedećem dijelu.

različite zakonske mjere za poticanje obrade neobrađenog obradivog poljoprivrednog zemljišta, korištenje neiskorištenih poduzetničkih nekretnina i izgradnju neizgrađenog građevinskog zemljišta, pa i one koje ograničavaju vlasnička prava u skladu s člankom 16. Ustava, odnosno člankom 52. stavkom 2. Ustava kad su u pitanju poljoprivredna zemljišta. To se, međutim, ne smije činiti na način nesuglasan temeljnim ustavnim vrednotama i zaštićenim dobrima, što je zakonodavac u konkretnom slučaju učinio propisivanjem poreza zbog nekorištenja nekretnina, koji su protivni svrsi poreza i poreznog sustava.“”

118 Staničić, F., op. cit., str. 121-126.

119 V. kao referentan, predmet James i ostali protiv Ujedinjenog Kraljevstva, zahtjev br. 8793/79, presuda od 12. srpnja 1984., §50.

120 Staničić, F., op. cit., str. 113.

121 Potomska i Potomski, $\S$ 64. Kozacioğlu protiv Turske, zahtjev br. 2334/03, presuda od 19. veljače 2009., § 54.

122 U odluci našeg Ustavnog suda koja se bavila prisilnim zakupom poljoprivrednog zemljišta, po ovim je pitanjima rečeno ,prisilni zakup ima legitiman cilj - povećanje poljoprivredne proizvodnje, odnosno stavljanje u funkciju nekorištenog poljoprivrednog zemljišta“, te naglašeno da je „propisan u interesu Republike Hrvatske (članak 52. Ustava)“, a sam zakup, kao ograničenje koje je vlasnicima nametnuto, načelno, u okvirima 'doprinosa općem dobru' (članak 48. stavak 2. Ustava)“.

123 Zahtjev br. 33949/05, presuda od 29. ožujka 2011., § 64. 


\subsection{Pravilo o kontroli korištenja imovine}

Kada se utvrdi da se država miješala u pravo na mirno uživanje imovine treba odgovoriti o kojem se od tri pravila iz članka 1. Protokola 1. S tim da su u novije vrijeme primjetna i nešto drukčija rješenja. Iscrpno objašnjavajući bit ovih pravila Omejec $^{124}$ je konstatirala kako je prvo od njih načelne naravi i koristi se kada nije moguće primijeniti preostala. Drugo se pravilo primjenjuje kada dođe do, tzv. oduzimanja vlasništva kao, npr. kod izvlaštenja, nacionalizacije, eksproprijacija, i sl. ${ }^{125} \mathrm{U}$ trećem pravilu, ujedno i najzanimljivijem u kontekstu privremene uprave, odnosno privremenog skrbništva, riječ je o, tzv. kontroli korištenja imovine, odnosno pravu država da regulira njezinu uporabu, pa i način izvršavanja vlasničkopravnih ovlasti na stvari, u konačnici da ih i ograniči. ${ }^{126}$ Usprkos opisanom razlikovanju, u teoriji se naglašava i više puta stavlja u prvi plan, da su ova pravila međusobno povezana, da se drugo i treće pravilo odnose i primjenjuje, u posebnim slučajevima miješanja, međutim da ih je uvijek potrebno razumjeti i tumačiti imajući u vidu prvo od njih, koje je najopćenitije i temeljne naravi. ${ }^{127}$

Što se tiče trećeg pravila, najprije treba reći da ga sadržava stavak 2., članka 1. Protokola $1 .{ }^{128}$ i da je primijenjeno u više predmeta ${ }^{129}$ (neki su navedeni u dijelu

124 Omejec, J., op. cit., str. 979- 990. V. kod, Sermet, L, op. cit., str. 22-31. Carss-Frisk, M., op. cit., str. 21-25.

125 Ima autora koji smatraju da je riječ o ovom pravilu, odnosno da ga je moguće primijeniti i onda kada je do oduzimanja ili prijenosa vlasništva došlo de facto. Grgić, A., Mataga, Z., Longar, M. Vilfan, A., The right to property under the European Convention on Human Rights, Human rights handbooks br. 10, Vijeće Europe, Strasbourg, 2007., dalje u tekstu: Grgić, A., et al., The right to property, str. 10, dostupno na: https://rm.coe.int, mrežna stranica posjećena 22 . siječnja 2019.

126 Između više odluka Europskog suda koje su se ticale Hrvatske s obzirom na kontrolu korištenja imovine, npr. Bego i ostali protiv Hrvatske, zahtjevi br. 35444/12, 35576/12, i dr., presuda od 15. studenog 2016.; Boljević protiv Hrvatske, zahtjev br. 43492/11, presuda od 31. siječnja 2017.; Gabrić protiv Hrvatske, presuda od 5. veljače 2009., zahtjev br. 9702/04; Gošović protiv Hrvatske, presuda od 4. travnja 2017., zahtjev br. 37006/13; Kunić; Matas; MiroševićAnzulović protiv Hrvatske, presuda od 4. listopada 2016., zahtjev br. 25815/14; Radanović; Statileo; Tilocca protiv Hrvatske, presuda od 5. travnja 2018., zahtjev br. 40559/12; Vučak; i dr.

127 Carss-Frisk, M., op. cit., str. 25 et seq.

128 Uporište miješanju, odnosno ovlast države da po vlastitom nahođenju i u okviru polja slobodne procjene kontrolira i ograniči pravo na mirno uživanje imovine u skladu s Konvencijom, kako naglašava Sermet, predstavlja navedena konvencijska odredba (stavak 2., članka 1.) i to, ili u skladu s općim interesom, ili zbog osiguranja plaćanja poreza ili drugih doprinosa ili kazni. Kontrola se u skladu s općim interesom, može usmjeriti i na ovlast raspolaganja imovinom. Sermet, L., op. cit., str. 25. Država, dakle, može kontrolirati korištenje imovine ako je to u općem interesu ili radi osiguranja plaćanja poreza ili drugih doprinosa ili kazni. U tom su smislu tzv. mjerama kontrole korištenja imovine smatrane primjerice, oduzimanje opscenih publikacija (Handyside protiv Ujedinjenog Kraljevstva, zahtjev br. 5493/72, presuda od 7. prosinca 1976.), kontrola najma (Mellacher protiv Austrije, zahtjev br. 11070/84, presuda od 19. prosinca 1989., Statileo), ograničenja u izgradnji (Pine Valley Developments Ltd. protiv Irske, zahtjev br. 12742/87, presuda od 29. studenog 1991.), privremeno oduzimanje predmeta u kaznenim postupcima (Raimondo protiv Italije, zahtjev br. 12954/87, presuda od 22. travnja 1994.) i brojni drugi.

129 Pine Valley Developments Ltd., Mellacher, Holy Monasteries protiv Grčke, 13984/88, presuda 
rada 3.4. zbog važnosti za pitanje razmjernosti), a na pitanje kada se primjenjuje i kojem ključu, Carss-Frisk jezgrovito odgovara „da je to u slučajevima miješanja koje je usmjereno ili, pak, predstavlja dio uređenja kojem je cilj kontrola korištenja imovine“. ${ }^{130}$ Bit trećeg pravila možda najbolje prenosi odlomak kada se jezikom Suda u predmeta Statileo navodi da se radi o: „mjeri, odnosno ograničenju koje predstavlja nadzor nad korištenjem imovine u smislu drugoga stavka članka 1. Protokola br. 1". ${ }^{131}$

\subsection{Razmjernost/proporcionalnost i pravična ravnoteža kao središnja pitanja}

Nakon što je utvrdio koje od pravila u konkretnom slučaju treba primijeniti, ${ }^{132}$ Sud pristupa središnjem dijelu testiranja i odgovara na ključna pitanja: Je li miješanje bilo razmjerno, odnosno, ,je li miješanjem u pravo na mirno uživanje imovine postignuta prijeko potrebna pravedna ravnoteža između zahtjeva općeg javnog interesa i zahtjeva zaštite temeljnih prava pojedinaca, te nameće li se podnositelju nerazmjeran i pretjerani teret."133

Unatoč tomu što države uživaju široko polje slobodne procjene, a u novijoj sudskoj praksi naglašeno je inzistiranje na postizanju pravične ravnoteže interesa pojedinaca i općeg interesa. ${ }^{134}$ Ključno je kod svakog ograničenja, pa i promatranog

od 9. prosinca 1994., i niz drugih. V. neke od hrvatskih predmeta u bilješci 114.

130 Carss-Frisk, M., op. cit., str. 24.

131 Statileo, § 117.

132 Prije rečeno je da su primjetne nove tendencije kod primjene i uopće u odnosu na tri pravila. Naime, moderan pristup djelomično je zamaglio, odnosno ukinuo razlike kod ispitivanja povreda prava na mirno uživanje imovine između različitih oblika miješanja, pa bi ih Sud vjerojatno danas razmatrao kao pitanje kontrole korištenja imovine (Sporrong $i$ Lonnroth). Zanimljivo je spomenuti da, prema ocjeni Suda, konfiskacija predstavlja i oduzimanje imovine i kontrola korištenja imovine.

133 Statileo, $\S 119-145$.

134 Ovaj je pristup dobro ilustriran još u predmetu Chassagnou i drugi protiv Francuske, zahtjevi br. 25088/94, 28331/95, 28443/95, presuda od 29. travnja 1999. i više drugih. Zajedničko im je da Sud naglašava potrebu ispunjenja uvjeta proporcionalnosti/razmjernosti. Kao primjer tzv. pilot presude kod pitanja kontrole korištenja imovine, a u kontekstu razmjernosti, odnosno pravične ravnoteže, Jacobs, White i Ovey naveli su presudu Suljagić protiv Bosne i Hercegovine, zahtjev br. 27912/02, presuda od 3. studenog 2009., gdje je Sud naglasio da zakon koji je donijela bosanska vlada vezan za naknadu depozita položenih kod banaka, zbog širokog polja slobodne procjene koji uživaju države, ne predstavlja povredu članka 1. Protokola broj 1. Međutim, pravična ravnoteža nije postignuta, s obzirom na kašnjenja do kojih je došlo u njegovoj implementaciji. Slično je Sud utvrdio u presudi Ališić i drugi protiv Bosne i Hercegovine, Hrvatske, Srbije, Slovenije i Bivše Jugoslavenske Republike Makedonije, zahtjev br. 60642/08, presuda od 16. travnja 2014., gdje je našao kako su Slovenija i Srbija povrijedile Konvenciju (kašnjenja s usvajanjem mjera, odnosno njihovim ne udovoljavanjem uvjetu proporcionalnosti, unatoč širokom polju slobodne procjene u pitanjima financijske stabilnost države); u predmetu Spadea i Scalabrino protiv Italije, zahtjev br. 12868/87, presuda od 28. rujna 1995. (gdje je Sud zaključio kako sustav kontrole korištenja imovine ima funkciju socijalne mjere zaštite stanara s malim prihodima i zadržavanja javnog/socijalnog mira, međutim predstavljala preveliki teret i nije postignuta pravična ravnoteža); i dr. U predmetu Nobel i drugi protiv Nizozemske, zahtjevi br. $27126 / 11,28084 / 12,81046 / 12,81049 / 12$, presuda od 2. srpnja 2013, Sud je smatrao 
zbog uspostavljanje privremene uprave, odnosno privremenog skrbništva je li država pojedincu nametnula prekomjeran teret i narušila pravičnu ravnotežu zbog čega bi miješanje bilo nerazmjerno. ${ }^{135} \mathrm{U}$ predmetu Ališić $i$ drugi u povodu ocjene jesu li države poštovale zahtjev pravične ravnoteže istaknuto je: „Svakim uplitanjem u mirno uživanje imovine, kao i propuštanjem (dakle, pozitivnim i negativnim obvezama države - op. aut.), mora se uspostaviti pravična ravnoteža između potreba općeg interesa zajednice i zahtjeva za zaštitu temeljnih prava pojedinca. Drugim riječima, u svakom slučaju u kojem je došlo do povrede članka 1. Protokola 1., Sud mora utvrditi da li osoba o kojoj je riječ mora podnijeti nerazmjeran i pretjeran teret uslijed djelovanja ili nedjelovanja države. Prilikom ocjene o poštovanju toga zahtjeva, Sud mora potpuno ispitati sve interese o kojima je riječ, imajući na umu ulogu Konvencije da štiti prava koja su 'praktična i efektivna' (načelo učinkovitosti - op. aut.). U tom smislu valja naglasiti da neizvjesnost, bilo da je ona legislativna, administrativna ili da proizlazi iz prakse koju vlasti provode, predstavlja čimbenik koji se mora imati u vidu kod ocjene ponašanja države. U slučajevima gdje je doista u pitanju opći interes, na državnim je tijelima da reagiraju u pravo vrijeme i na odgovarajući i dosljedan način (doktrina predvidljivosti)" § 108. Opći zahtjevi (načela) na temelju kojih treba ocijeniti razmjernost ograničenja, a konkretno kada je riječ o miješanja u pravo na mirno uživanje imovine vezano za zaštićena dobra mogu se pročitati u predmetu Potomska i Potomski na koji se Sud često poziva i u kojem je naglašeno da „,imovina, pa i ona privatna, ima i socijalnu funkciju koju je potrebno uzeti u obzir prilikom ocjene je li postignuta pravična ravnoteža između zahtjeva općeg interesa zajednice i temeljnih prava pojedinaca“, $\S 67$. Zapravo, jednako kao i u predmetu Depalle protiv Francuske,${ }^{136}$ ponovljena je struktura na kojoj Sud inzistira kod ove vrste ograničenja, a omeđena je trokutom: širina polja slobodne procjene - opći interes - pravična ravnoteža. Riječ je o posebno osjetljivim predmetima i nikome ne pada na pamet dovoditi u pitanje legitimitet zaštite kulturnih dobara ${ }^{137}$ i sličnih dobara, pa je još minucioznije potrebno uspostaviti željeni balans između općeg interesa i prava na mirno uživanje imovine. Kao kriteriji u spomenutom odlomku predmeta Potomska i Potomski u službi utvrđenja (ne)razmjernosti navedeno je trajanje mjera (zapravo, ograničenja) i već dobro poznat zahtjev udovoljenja, tzv. postupovnim jamstvima. ${ }^{138}$

nedopuštenim zahtjev podnositelja koji su tvrdili da su mjere kontrole visine najamnine neproporcionalne, budući da široko polje slobodne procjene koje država uživa omogućava da odredi maksimalnu visinu najamnine radi socijalne zaštite najmoprimaca, a podnositelji su bili upoznati s kontrolom korištenja imovine kada su kupili nekretnine.

135 U jednom od poznatijih predmeta koji ulazi u krug onih kojima pripada naš predmet Statileo, Bitto i ostali protiv Slovačke, zahtjev br. 30255/09, presuda od 28. siječnja 2014., u pogledu razmjernosti kazano je da „mora postojati razumna veza razmjernosti između korištenih sredstava i predviđenog cilja koji se želi postići mjerama koje provodi država radi kontrole nad korištenjem imovine pojedinaca. Taj je zahtjev izražen pojmom 'poštene ravnoteže' koja se mora postići između zahtjeva općeg interesa zajednice i zahtjeva zaštite temeljnih prava pojedinca“", § 97.

136 Zahtjev br. 34044/02, presuda od 29. ožujka 2010., §§ 77-93.

137 V. općenito, kod Josipović, T., Zaštita kulturnih dobara u Europskoj uniji u: Gavella, N., et alt., Europsko privatno pravo, str. 197-146.

138 U našem predmetu Matas, za razliku od spomenutog predmeta i predmeta Kristiana Ltd., gdje 
Uvažavajući da po ovim pitanjima država uživa široko polje slobodne procjene, ključno je pitanje bilo ono o razmjernosti mjera u kojem kontekstu su problematizirani navedeni aspekti. U pogledu duljine trajanja mjera u predmetu Matas $^{139}$ naglašeno je da: ,podnositelj zahtjeva ne bi trebao snositi bilo kakve negativne posljedice kao rezultat navodne nemogućnosti nadležnih državnih tijela da usklade svoje mjerodavne radnje kod odlučivanja o pitanjima koja utječu na njegovo pravo vlasništva“. ${ }^{140}$ Drugi aspekt ticao se: ,više postupovnih propusta u odnosu na način na koji su domaća tijela provodila postupak u predmetu podnositelja zahtjeva... pa, iako članak 1. Protokola 1. ne sadrži izričite postupovne zahtjeve, predmetni postupak mora pružiti osobi razumnu priliku da predstavi svoj slučaj mjerodavnim tijelima u svrhu učinkovitog osporavanja mjera koje ometaju prava zajamčena ovom odredbom. Pri utvrđivanju je li taj uvjet zadovoljen, uzima se u obzir cjelokupna slika“, Matas $\S 44 .{ }^{141}$ Sve je ovo, zapravo ponovio i u recentnom predmetu, Kristiana Ltd.

Nekoliko puta samo se referirali na odluku Ustavnog suda o prisilnom zakupu poljoprivrednog zemljišta. Ona je najzanimljivija baš u dijelu u kojoj je ocjenjena razmjernost prisilnog zakupa i neke njegove kondicije. U tom kontekstu spomenuti će se i pitanje naknade kao još jednog od pokazatelja razmjernosti ograničenja. Općenito govoreći, analiza članka 15. ZPZ/08-a koncentrirala se na usklađenosti rješenja o mogućnosti prisilnog zakupa uopće (za kojeg je već rečeno da je prihvatljiv), odnosno zakupa poljoprivrednog zemljišta u privatnom vlasništvu koje se, ili nije obrađivalo sukladno agrotehničkim mjerama, ili se nije obrađivalo u prethodnom vegetativnom razdoblju, a dalo se u zakup fizičkoj ili pravnoj osobi na rok do tri godine. Obje pretpostavke ocjenjene su ustavnopravno neprihvatljivim. ${ }^{142}$ Nerazmjernim je

su podnositelji zahtjeva znali za postojanje mjera (jer su, u biti stekli vojne zgrade u ovom režimu), ništa nije ukazivalo da su se mjere zaštite kulturnog dobra mogle primjenjivati nad zgradom koju je podnositelj kupio u poslovne svrhe, što je vlastima bilo poznato (Matas, § 37.). Ključno je, naime, bilo to što je rješenjem konzervatorskog odjela produžena primjena mjere preventivne zaštite kulturnog dobra za dodatno trogodišnje razdoblje (ukupno šest godina). Ta je zaštita uključila više značajnih ograničenja podnositeljeva korištenja zgrade, uključivo njezinu gospodarsku upotrebu na način koji je podnositelj smatrao primjerenim. Matas, § 3839.

139 Ovdje se otklonio prigovor konzervatorskog odjela o nemogućnosti pribavljanja izvatka iz zemljišnih knjiga.

140 Ovdje je istaknuta važnost načela dobrog upravljanja.

141 Između ostalog, „primijećeno je da je, unatoč jasnim argumentima podnositelja zahtjeva u vezi s ograničenjima njegovog prava vlasništva, pogotovo u odnosu na njegove poslovne projekte povezane sa zgradom Upravni sud Republike Hrvatske ograničio svoju procjenu na pitanje moguće važnosti zgrade kao kulturnog dobra, a da nije ocijenio je li produžena primjena navedenih mjera nerazmjerno utjecala na pravo vlasništva podnositelja zahtjeva“, Matas, $\S \S$ 45-46.

142 Za prvu se kaže da „,ne obrađivanje zemljišta sukladno agrotehničkim mjerama može i mora biti osnova za poduzimanje određenih mjera radi postizanja zakonskog cilja - obrade zemljišta sukladno agrotehničkim mjerama. Međutim, mjere moraju biti primjerene činjeničnim okolnostima i razmjerne cilju koji se želi postići. K tome, u ostvarenju legitimnog cilja trebaju u što većoj mjeri omogućiti i održati privatnu upotrebljivost vlasništva. To uključuje i uvažavanje gospodarskih mogućnosti onih na koje se dotične mjere imaju primijeniti. Prisilno davanje u zakup... nije mjera koja odgovara načelu razmjernosti, jer lišava vlasnika privatne 
smatrano i rješenje koje se ticalo „nepostojanja pravnih sredstava kojima se vlasnik može zaštititi od nezakonitog ili arbitrarnog miješanja javnih vlasti u njegova vlasnička prava“", ${ }^{143}$ a vidjelo se u predmetima Potomska i Potomski te Matas, koliko su relevantne Europskom sudu. Ustavnopravno prihvatljivom nije ocjenjena niti predviđena naknada zakupnine. Ovo je pitanje već najavljeno kao mogući pokazatelj razmjernosti i treba imati u vidu da ga Sud ne promatra jednoznačno. U našem ustavnosudskom predmetu, s obzirom na zakupninu, Ustavni se sud osvrnuo na sadržaj zakupa poljoprivrednog zemljišta u privatnom vlasništvu kojim se „u cijelosti lišava vlasnika njegova posjeda, a time i privatne upotreblijivosti samog vlasništva zbog toga, tzv. prisilni zakup ,mjerom takvog intenziteta da za posljedicu ima lišavanje vlasnika biti njegova vlasničkog prava na poljoprivrednom zemljištu“, a da pritom „svojstvo privremenosti takvog ograničenja ne umanjuje snagu njegova intenziteta, sve dok ono traje“ zaključeno je da je ,za ograničenje vlasničkih prava iz članka 15. ZPZ/08-a potrebna 'naknada tržišne vrijednosti' iz članka 50. stavka 1. Ustava“". Europski sud svoja stajališta kreira u konkretnim slučajevima, kao, primjerice u sljedeća dva. Tako je u predmetu Jahn i drugi protiv Njemačke, ${ }^{144}$ središnje pitanje bilo povezano s činjenicom da je omogućeno stjecanje prava vlasništva na prethodno ekspropriranom zemljištu, unatoč tomu što je utvrdilo da je došlo do oduzimanja imovine, Veliko vijeće zaključilo: kako je postojala zakonska osnova za oduzimanje imovine; da je ono služilo legitimnom cilju, te ispitujući je li postignuta pravična ravnoteža između pojedinačnog i općeg interesa zaključilo (za razliku od Vijeća) kako je u konkretnom slučaju izostanak naknade opravdan. Jednako nije zaključeno u predmetu Holy Monasteries u kojem je izostanak naknade prouzročio povredu članka 1. Protokola 1.

\section{ZAKLJUČAK}

U radu je analizirano uređenje sekvestracije kao instituta kojim je omogućeno javnoj vlasti da vlasniku privremeno ograniči izvršavanje vlasničkopravnih ovlasti na stvari (nekretnini) ako se od njega tražilo određeno činjenje u vezi sa stvari koje on nije učinio. Usprkos Ustavom zajamčene nepovredivosti vlasništva, vlasništvo je

upotrebljivosti njegova vlasništva, a da ZPZ-e istodobno ne predviđa nikakve druge mjere za postizanje istog legitimnog cilja koje bi prethodile mjeri prisilnog zakupa, a kojima bi se manje zadiralo u prava vlasnika poljoprivrednog zemljišta.“ Prigovori upućeni drugoj pretpostavci „o neobrađivanju zemljišta kroz prethodno vegetativno razdoblje“ ocijenjeno je nerazmjernim u kontekstu važenja propisa ratione temporae.

143 Navodi se i: „Konkretno, u državi utemeljenoj na vladavini prava nije prihvatljivo poduzimanje prisilnih mjera kojima se vlasnika lišava na određeno vrijeme upotrebljivosti njegova vlasništva, a da protiv takvih mjera on nema na raspolaganju djelotvorna pravna sredstva kojima bi se zaštitio od nezakonitog ili arbitrarnog miješanja javnih vlasti u njegova vlasnička prava.“ Rečeno je i: „Doda li se tome i propust zakonodavca da predvidi put pravne zaštite koji bi vlasnicima poljoprivrednih zemljišta obraslih višegodišnjim raslinjem bio na raspolaganju protiv odluke o prisilnom davanju u zakup takvog zemljišta, rješenje iz članka 15. stavka 2. ZPZ/08-a ukazuje se nesuglasnim s jamstvom prava vlasništva u materijalnom aspektu (članak 16. stavak 1. u vezi s člankom 48. stavkom 1. Ustava) i s načelom vladavine prava (članak 3. Ustava), zasebno i u vezi s člankom 48. stavkom 1. Ustava u njegovu procesnom aspektu“.

144 Zahtjevi, br. 46720/99, 72203/01, 72552/01, presuda od 30. lipnja 2005. 
moguće ograničiti, ali ograničenja trebaju biti predviđena zakonom i služiti zaštiti interesa i sigurnosti države, prirode, ljudskog okoliša i zdravlja ljudi. Privremena je uprava posebna vrsta pozitivnoga zakonskog ograničenja predviđenog u članku 32. ZV-a i u nekim posebnim pravilima. Uspostavlja se kada je potrebno zaštititi interese i sigurnost države, prirode, ljudskog okoliša i zdravlja ljudi te kulturnih dobara kojima prijeti ugroza (članak 32. stavak 3 . ZV-a).

Europski sud pruža zaštitu pravu na mirno uživanje imovine, jednako kao i drugim konvencijskim pravima, kada ga je država ugovornica povredom svojih obveza, pozitivnih ili negativnih, ${ }^{145}$ ugrozila ili mu naškodila. Odnosno, kada je država propustila zaštititi konvencijski zaštićeno pravo podnositelja zahtjeva (ovdje iz članka 1. Protokola 1.) ili je, proširujući polje slobodne procjene ograničenjima nametnutima pojedincu narušila pravičnu ravnotežu. Kada se radi o privremenoj upravi, odnosno privremenom skrbništvu ovi su slučajevi osobito osjetljivi, budući da se na određeni način opći interes sukobljava s pravom pojedinca na mirno uživanje imovine. Tim povodom, Sud, vrlo ilustrativno, u predmetu Matas ističe da je: „neprijeporna dužnost države očuvati i zaštiti kulturna dobra i njihovom održivom uporabom težiti legitimnom cilju održavanja određene kvalitete života, očuvanju povijesnih, kulturnih i umjetničkih korijena neke regije i njezinog stanovništva," pa sama činjenica postojanja ograničenja nije problematična i ono je legitimno. Usprkos tomu, potrebno je očuvati pravičnu ravnotežu između općeg i interesa pojedinca, da pojedincu nije nametnut prekomjeran teret te da se, u konačnici, ograničenje nije pokazalo nerazmjernim i time povrijedilo pravo na mirno uživanje imovine.

U radu analizirana uređenja privremene uprave, odnosno privremenog skrbništva u našem pravu predviđaju određena rješenja koja potencijalno mogu biti problem u kontekstu zaštite prava iz članka 1 . Protokola 1.

Prema članku 32. stavku 3. ZV-a, privremenu upravu uspostavlja općinski načelnik, gradonačelnik, odnosno župan i to odgovarajućom primjenom pravila o privremenom skrbništvu nad ostavinom iz članka 128. ZN-a, osim ako posebni zakon ne određuje što drugo. Navedeni članak uređuje slučaj kada sud postavlja privremenog skrbnika ostavini ako su nasljednici nepoznati ili nepoznatoga boravišta i pitanje je u kojoj je mjeri moguća njegova odgovarajuća primjena na privremenu upravu, pa, makar samo zbog toga što ju ne određuje sud. Nije za očekivati niti da sekvestar ima baš sve one ovlasti koje ima privremeni skrbnik ostavine postavljen po sudu (npr. ovlašten je u ime nasljednika tužiti i biti tužen, naplatiti tražbinu ili isplatiti dug i uopće zastupati nasljednike, a mogu mu se odrediti i druge, posebne ovlasti i dužnosti). Posebno je pitanje kontrole njegova rada, a svakako važnije i ono o naknadi troškova koje je prouzročio i o nagradi koja mu se daje za rad. Prema općem pravilu o sekvestraciji, predviđeno je da se za ova pitanja primjene pravila o naknadi troškova i nagradi izvršitelju oporuke. Prema njima (riječ je o članku 62. ZN-a), izvršitelju oporuke troškovi i nagrada isplaćuju na teret ostavine, ali uz zahtjev da se time ne umanji nužni nasljedni dio. U općem se režimu privremene uprave, dakle, vodi računa

145 Shvatimo li ih na način kako ih definira Omejec kada navodi da je bit negativnih obveza država u tome da se suzdrže od miješanja u zajamčeno pravo, a pozitivnih da uspostave odgovarajući normativni okvir koji omogućuje učinkovitu zaštitu. Omejec, J., ibidem. 
o tome da se stvar pretjerano ne ugrozi isplatom troškova i nagrade i nije predviđena mogućnost osiguranja tih tražbina. U posebnim režimima predviđaju se drukčija rješenja, pa je, primjerice, za osiguranje troškova i nagrade privremenog skrbnika na kulturnom dobru moguće osnovati zakonsko založno pravo. Prema još posebnijem pravilu, otuđi li vlasnik građevinu u koju su uložena sredstva Zavoda, a stjecatelj nije nasljednik prvoga nasljednog reda, dužan je prije otuđenja vratiti uložena sredstva, a za njihovo osiguranje Zavod stječe zakonsko založno pravo u trajanja od 15 godina (članak 21. ZOSCDDNKDOD-a).

Da bi se uspostavila privremena uprava potrebno je od vlasnika tražiti određeno činjenje u vezi sa stvari, pa da ga on nije učinio što, gotovo, da ima značenje objektivne pretpostavke. Naime, ne gledaju se razlozi zbog kojih je činjenje izostalo, a upravo je uređenje koje nije uvažilo okolnosti konkretnog slučaja ocjenjeno od strane Ustavnog suda ustavnopravno problematičnim kada se radilo o zahtjevu vlasniku da poljoprivredno zemljište obrađuje sukladno agrotehničkim mjerama i kazano je da treba biti primjereno činjeničnim okolnostima i razmjerno cilju koji se želi postići.

Osnovno obilježje privremene uprave trebalo bi biti njezino privremeno trajanje. Pokazao je ovo i predmet Matas u kojem je Europski sud nerazmjernima i neprihvatljivima ocijenio poduzete mjere preventivne zaštite kulturnog dobra koje su trajale šest godina, pa potencijalno problematična mogu biti rješenja kojim nije adekvatno artikulirana privremena narav privremene uprave, odnosno privremenog skrbništva.

Privremena uprava, odnosno privremeno skrbništvo predstavlja posebno zakonsko ograničenje vlasništva i u ovom smislu promatrano je u okviru zaštite prava na mirno uživanje imovine s obzirom na treće pravilo o kontroli korištenja imovine iz članka 1. stavka 2. Protokola 1. Iako se, naime, uspostavom privremene uprave, odnosno privremenog skrbništva sadržaj prava vlasništva ne mijenja, već se vlasnika (privremeno) ograničava u izvršavanju njegovih vlasničkopravnih ovlasti dok uprava, odnosno skrbništvo traje, jedno od ključnih pitanja, pa i potencijalne konvencijske zaštite jest upravo ono vezano uz opseg i razmjernost ograničenja. Ne jednom je naglašena potreba da se ne naruši pravična ravnoteža i da ograničenje bude razmjerno. Našim općim pravilima dopušteno je sekvestriranu nekretninu dati u zakup, s tim što vlasnik može tražiti da mu se vrati u posjed prije isteka zakupa (sličnu ovlast predviđa i ZPZ-e, ali ne prije negoli prođe pet godina od uvođenja zakupnika u posjed). U vezi $\mathrm{s}$ tom mogućnosti (da se sekvestrirana nekretnina dade u zakup) može se primijetiti da u općim pravilima nije predviđeno kako će određivati zakupnina, već je samo određuje u što ju je moguće utrošiti (ovo je pitanje detaljnije uređeno u posebnim režima). Tako uređenje može provocirati konvencijske prigovore, jer, iako Europski sud u nekim predmetima u kojima nije dana naknada za oduzimanje (kontroliranje) imovine takvo što nije smatrao povredom prava na mirno uživanje imovine, ipak, su takva stajališta zauzeta rijetko i ne može se reći da predstavljaju pravilo. Dapače, baš suprotno, pa je zbog toga korisno, uvijek kada se pojavljuje pitanje naknade, a ovdje takvu ulogu ima zakupnina, predvidjeti mehanizme na koji će se način ona odrediti. Ovo udovoljava još jedno važnom zahtjevu, tzv. predvidljivosti. Nije, naime, potrebno naglašavati koliko je puta Sud ponovio, ponajprije štiteći pravo iz članka 
6. Konvencije, ali i druga prava, da zaštita koja se pruža Konvencijom mora biti predvidljiva, dostupna i učinkovita (načelo učinkovitosti). Naravno, omogućava i da se ispita je li narušena pravična ravnoteža između općeg interesa i prava pojedinca na mirno uživanje imovine i donese zaključak o (ne)razmjernosti ograničenja.

\section{LITERATURA}

1. Belaj, Vlado, Klasiček, Dubravka, Novije tendencije u ograničavanju prava vlasništva, Pravni vjesnik, vol. 21., 3-4/2005., str. 211-234.

2. Beširević, Violeta, Popović, Dragoljub, Leskoviku, Migena, Marinković, Tanasije, Studija o primjeni prakse Europskog suda za ljudska prava u upravnim sporovima (ur. Beširević, V.), Regionalna škola za javnu upravu (ReSPA), Danilovgrad, 2018.

3. Bogdanović, Tamara, Zaštita prava vlasništva iz članka 1. Protokola 1. Europske konvencije u praksi Upravnog suda Republike Hrvatske, Zbornik Pravnog fakulteta Sveučilišta u Rijeci, vol. 32, 1/2011., str. 583-598.

4. Branković, Goran, Sudska praksa i upravni spor, doktorski rad, Univerzitet u Nišu, Pravni fakultet, Banja Luka, 2012.

5. Carss-Frisk, Monica, The right to property: A guide to the implementation of article 1 of protocol No. 1 to the European Convention on Human Rights, Human rights handbooks br. 4. Vijeće Europe, Strasbourg, 2001.

6. Crnić Grotić, Vesna, Zaštita prava vlasništva u međunarodnom pravu, Zbornik Pravnog fakulteta Sveučilišta u Rijeci, vol. 22., 1/2001., str. 361-375.

7. Crnić, Ivica, Ustav Republike Hrvatske u praksi, Zagreb, Organizator, 2018.

8. Elijaš, Dragan, Marković, Sandra, Trgovac, Sanja, Povreda konvencijskog prava na mirno uživanje vlasništva, Zbornik Pravnog fakulteta Sveučilišta u Rijeci, vol. 36, 1/2015., str. 239-258.

9. Ernst, Hano, Poljanec, Kristijan, Stvarnopravna i carinskopravna zaštita kulturnih dobara u svjetlu europske antiterorističke politike, Zbornik Pravnog fakulteta Sveučilišta u Rijeci, vol. 38., 1/2017., str. 187-222.

10. Gams, Andrija, Svojina, 2. izd., Beograd, Naučna knjiga, 1988.

11. Gavella, Nikola, Alinčić, Mira, Hrabar, Dubravka, Gliha, Igor, Josipović, Tatjana, Korać, Aleksandra, Baretić, Marko, Nikšić, Saša: Europsko privatno pravo, (ur. Dubravka, Hrabar), Zagreb, Pravni fakultet u Zagrebu, 2002.

12. Gavella, Nikola, Jamstvo vlasništva iz članka 1. Prvog protokola uz Europsku konvenciju za zaštitu ljudskih prava i temeljnih sloboda, u: Gavella, Nikola, Alinčić, Mira, Hrabar, Dubravka, Gliha, Igor, Josipović, Tatjana, Korać, Aleksandra, Baretić, Marko, Nikšić, Saša: Europsko privatno pravo, (ur. Dubravka Hrabar), Zagreb, Pravni fakultet u Zagrebu, 2002.

13. Gavella, Nikola, Josipović, Tatjana, Gliha, Igor, Belaj, Vlado, Stipković, Zlatan, Stvarno pravo, sv. 1., 2. izd., Zagreb, Narodne novine, 2007.

14. Gomien, Donna, Europska konvencija o ljudskim pravima, Zadar, Naklada, 2007.

15. Grbić, Sanja, Pošteno suđenje u građanskim postupcima u Hrvatskoj u svjetlu članka 6., stavka 1. Europske konvencije o ljudskim pravima, Rijeka, Pravni fakultet u Rijeci, 2014.

16. Grgić, Aida, Mataga, Zvonimir, Longar, Matija, Vilfan, Ana, The right to property under the European Convention on Human Rights, Human rights handbooks, br. 10., Strasbourg, Vijeće Europe, 2007.

17. Harris, John David, O' Boyle, Michael, Bates, Ed, Buckley, Carla, Law of the European Convention on Human Rights, $5^{\text {th }}$ ed, Oxford, Oxford University Press, 2014.

18. Held, Mateja, Primjena Europske konvencije za zaštitu ljudskih prava i temeljnih sloboda u praksi Ustavnog suda Republike Hrvatske, Hrvatska i komparativna javna uprava, vol. 16., 3/2016., str. 527-551. 
19. Josipović, Tatjana, Stvari u vlasništvu države i drugih osoba javnog prava (javno vlasništvo), Zbornik Pravnog fakulteta Sveučilišta u Rijeci, vol. 22, 1/2001., str. 95-153.

20. Josipović, Tatjana, Zaštita kulturnih dobara u Europskoj uniji u: Gavella, Nikola, Alinčić, Mira, Hrabar, Dubravka, Gliha, Igor, Josipović, Tatjana, Korać, Aleksandra, Baretić, Marko, Nikšić, Saša, Europsko privatno pravo, (ur. Dubravka Hrabar), Zagreb, Pravni fakultet u Zagrebu, 2002.

21. Klarić, Petar, Vedriš, Martin, Građansko pravo, Zagreb, Narodne novine, 2003.

22. Komnenić, Dušanka, Pravo na mirno uživanje imovine u presudama i odlukama Europskog suda za ljudska prava donijetim u postupcima u kojima su bivše jugoslavenske republike bile odgovorne države, doktorski rad, Beograd, 2017.

23. Kontrec, Damir, Boić, Vitomir, Konvencija za zaštitu ljudskih prava i temeljnih sloboda i praksa ESLJP - građanskopravni aspekti, Priručnik za voditelje/voditeljice, Zagreb, Pravosudna akademija, 2017.

24. Marković, Sandra, Trgovac, Sanja, Ustavna tužba i zahtjev Europskom sudu za ljudska prava - analiza i značaj tih pravnih sredstava, Aktualnosti hrvatskog zakonodavstva i pravne prakse, Godišnjak 25., Organizator, Zagreb, 2018.

25. Marković, Sandra., Radin, Marijana, Trgovac, Sanja, Ustavna zaštita prava vlasništva u svijetlu stavova Ustavnog suda Republike Hrvatske, Zbornik Pravnog fakulteta u Rijeci, vol. 32.,1/2011., str. 598-631.

26. Mihelčić, Gabrijela, Marochini Zrinski, Maša, Utjecaj konvencijskih načela tumačenja na pojedine građanskopravne institute (odabrana pitanja), Zbornik radova Pravnog fakulteta u Nišu, br. 78., 2018., str. 127-147.

27. Mihelčić, Gabrijela, Marochini Zrinski, Maša, Utjecaj zaštite „konvencijskih“ prava na ugovor o najmu stana, XIII Majsko savetovanje: Uslužno pravo (ur. Miodrag Mićović), Kragujevac, Ministarstvo prosvjete, nauke i tehnološkog razvoja, 2017.

28. Mihelčić, Gabrijela, Ovlaštenje hipotekarnih vjerovnika na namirenje hipotekarne tražbine sekvestracijom nekretnine de lege lata i de lege ferenda, u: Liber Amicorum in honorem dr. sc. Jadranko Crnić (1928.-2008.), Zagreb, Novi Informator, 2009.

29. Omejec Jasna, Konvencija za zaštitu ljudskih prava i temeljnih sloboda u praksi Europskog suda za ljudska prava, Strasburški acquis, Zagreb, Novi informator, 2013.

30. Perkušić, Ante, (Ne)usklađenost opće i posebne stvarnopravne normative o stjecanju, vrstama i sadržaju prava služnosti u našem pozitivnom pravu, Zbornik Pravnog fakulteta Sveučilišta u Rijeci, vol. 37., 1/2016., str. 201-249.

31. Praktični vodič kroz uvjete dopuštenosti, Strasbourg, Vijeće Europe, 2014.

32. Prančić, Vicko, Opasnost od rušenja zgrade, Zbornik Pravnog fakulteta u Rijeci, vol. 31, 2/2010., str. 845-877.

33. Radolović, Aldo, Jamstvo prava vlasništva u praksi Ustavnog suda Republike Hrvatske i Europskog suda za ljudska prava, sredstava, Aktualnosti hrvatskog zakonodavstva i pravne prakse, Godišnjak 16., Zagreb, Organizator, 2009.

34. Rainey, Bernardette, Wicks, Elizabeth, Ovey, Clare, Jacobs, White and Ovey: The European Convention on Human Rights, $7^{\text {th }}$ ed, Oxford University Press, 2017.

35. Rušnov, Adolfo, Šilović, Josip, Tumač Gradjanskom parbenom postupniku, Zagreb, Knjižara Lav. Hartman (Kugli i Deutsch)

36. Sarvan, Desanka, Postupanje sa zgradama od kojih prijeti opasnost od nastanka štete, Informator, 2001., br. 4986.

37. Sermet, Laurent, The European Convention on Human Rights and property rights, 2. pon. izd., Strasbourg, Vijeće Europe, 1999.

38. Seršić, Vanja, Nakić, Jakob, Upravljanje dobrima u vlasništvu jedinica lokalne samouprave, Zbornik Pravnog fakulteta Sveučilišta u Rijeci, vol. 34., 1/2013., str. 561-588.

39. Simonetti, Petar, Vlasništvo i njegove transformacije, jamstvo i zaštita u ustavnom poretku Republike Hrvatske, Zbornik Pravnog fakulteta u Rijeci, v. 31, 1. Suppl./2010., str. 333-364. 
40. Staničić, Frane, Razlikovanje javnog interesa, općeg interesa i interesa Republike Hrvatske u kontekstu javnopravnih ograničenja prava vlasništva, Zbornik radova Pravnog fakulteta u Splitu, god. 55, 1/2018., str. 111-129.

41. Stanković, Obren, Orlić, Miodrag, Stvarno pravo, 3. izd., Beograd, Naučna knjiga, 1986.

42. Stažnik, Štefica, Europski sud za ljudska prava i standardi upravnosudskog postupka, u: Europeizacija upravnog sudovanja u Hrvatskoj (ured. Ivan Koprić,), Zagreb, Institut za javnu upravu, 2014.

43. Stojanović, Dragoljub, Stvarno pravo, 5. izd, Beograd, Službeni list SFRJ, 1980.

44. Tuhtan Grgić, Iva, Ograničenja prava vlasništva u postupku urbane komasacije, Zbornik Pravnog fakulteta u Rijeci, v. 32., br. 1/2011, str. 633-657.

45. Vuković, Mihajlo, Osnovi Stvarnog prava, Zagreb, Nakladni zavod Hrvatske, 1950.

46. Žuvela, Mladen, Vlasničkopravni odnosi, Zakon o vlasništvu i drugim stvarnim pravima, Zakon o zemljišnim knjigama, Organizator, Zagreb, 2014.

Popis odluka Europskog suda:

1. Ališić i drugi protiv Bosne i Hercegovine, Hrvatske, Srbije, Slovenije i Bivše Jugoslavenske Republike Makedonije, zahtjev br. 60642/08, presuda od 16. travnja 2014.

2. Almeida Garrett, Mascarenhas Falcao i drugi protiv Portugala, zahtjevi br. 29813/96, 30229/96, presuda od 11. siječnja 2000.

3. Anheuser-Busch Inc. protiv Portugala, zahtjev br. 73049/01, presuda od 11. siječnja 2001.

4. Bego $i$ ostali protiv Hrvatske, zahtjevi br. 35444/12, 35576/12, i dr., presuda od 15. studenog 2016.

5. Bikić protiv Hrvatske, zahtjev br. 50101/12, presuda od 29. svibnja 2018.

6. Bistrović protiv Hrvatske, zahtjev br. 25774/05, presuda od 31. svibnja 2007.

7. Bitto i ostali protiv Slovačke, zahtjev br. 30255/09, presuda od 28. siječnja 2014.

8. Boljević protiv Hrvatske, zahtjev br. 43492/11, presuda od 31. siječnja 2017.

9. Bramelid i Malmstrom protiv Švedske, zahtjevi br. 8588/79, 8589/79, odluka od 12. listopada 1982.

10. Brezovec protiv Hrvatske, zahtjev br. 13488/07, presuda od 29. ožujka 2011.

11. Burdov protiv Rusije [VV], zahtjev br. 54522/00, presuda od 3. travnja 2012.

12. Chassagnou i drugi protiv Francuske, zahtjevi br. 25088/94, 28331/95, 28443/95, presuda od 29. travnja 1999.

13. De Napoles Pacheco protiv Belgije, zahtjev br. 7775/77, odluka od 5. listopada 1978.

14. Depalle protiv Francuske, zahtjev br. 34044/02, presuda od 29. ožujka 2010.

15. Gabrić protiv Hrvatske, presuda od 5. veljače 2009., zahtjev br. 9702/04

16. Gaćeša protiv Hrvatske, zahtjev br. 43389/02, odluka od 1. travnja 2008.

17. Gasus Dosier i Fördertechnik GmbH protiv Nizozemske, Zahtjev br. 15375/89, presuda od 23. veljače 1995 .

18. Gogitidze i drugi protiv Gruzije, Zahtjev br. 36862/05, presuda od 12. svibnja 2015.

19. Gošović protiv Hrvatske, zahtjev br. 37006/13, presuda od 4. travnja 2017.

20. Gratzinger i Gratzingerova protiv Češke, zahtjev br. 39794/98, odluka od 10 srpnja 2002.

21. H. protiv Belgije, zahtjev br. 8950/80, presuda od 30. studenog 1987.

22. Handyside protiv Ujedinjenog kraljevstva, zahtjev br. 5493/72, presuda od 7. prosinca 1976.

23. Hava Yolları Turizm ve Ticaret Anonim Şirketi protiv Irske, Zahtjev br. 45036/98, presuda od 30. lipnja 2005.

24. Holy Monasteries protiv Grčke, 13984/88, presuda od 9. prosinca 1994.

25. Ivanova i Cherkezov protiv Bugarske, zahtjev br. 46577/15, presuda od 21. travnja 2016.

26. Jahn i drugi protiv Njemačke, zahtjevi br. 46720/99, 72203/01, 72552/01, presuda od 30. lipnja 2005.

27. James i ostali protiv Ujedinjenog kraljevstva, zahtjev br. 8793/79, presuda od 12. srpnja 1984. 
28. Kopecký protiv Slovačke, Zahtjev br. 44912/98, presuda od 28. rujna 2004.

29. Kozacioğlu protiv Turske, zahtjev br. 2334/03, presuda od 19. veljače 2009.

30. Kristiana Ltd. protiv Litve, zahtjev br. 36184/13, presuda od 6. veljače 2018.

31. Kunić protiv Hrvatske, zahtjev br. 22344/02, presuda od 11. siječnja 2007.

32. Matas protiv Hrvatske, zahtjev br. 40581/12, presuda od 4. listopada 2016.

33. Mellacher protiv Austrije, zahtjev br. 11070/84, presuda od 19. prosinca 1989.

34. Mirošević-Anzulović protiv Hrvatske, zahtjev br. 25815/14, presuda od 4. listopada 2016.

35. Olczak protiv Poljske, zahtjev br. 30417/96, odluka od 7. studenog 2002.

36. Pine Valley Developments Ltd protiv Irske, zahtjev br. 12742/87, presuda od 29. studenog 1991.

37. Plechanow protiv Poljske, zahtjev br. 22279/04, presuda od 7. srpnja 2009.

38. Potomska i Potomski protiv Poljske, zahtjev br. 33949/05, presuda od 29. ožujka 2011.

39. Prince Hans-Adam II of Liechtenstein protiv Njemačke, zahtjev br. 42527/98, presuda od 12. srpnja 2001.

40. Radanović protiv Hrvatske, presuda od 21. prosinca 2006., zahtjev br. 9056/02, presuda od 21. prosinca 2006.

41. Radomilja i drugi protiv Hrvatske, zahtjevi br. 37685/10, 22768/12, presuda od 20. ožujka 2018

42. Raimondo protiv Italije, zahtjev br. 12954/87, presuda od 22. travnja 1994.

43. SCEA Ferme de Fresnoy protiv Francuske zahtjev br. 61093/00, odluka od 1. prosinca 2005.

44. Slivenko i drugi protiv Latvije [VV], zahtjev br. 48321/99, odluka od 9. listopada 2003.

45. Spadea i Scalabrino protiv Italije, zahtjev br. 12868/87, presuda od 28. rujna 1995. Nobel i drugi protiv Nizozemske, zahtjevi br. 27126/11, 28084/12, 81046/12, 81049/12, presuda od 2. srpnja 2013.

46. Statileo protiv Hrvatske, Zahtjev br. 12027/10, presuda od 10. srpnja 2014.

47. Stec i drugi protiv Ujedinjenog Kraljevstva [VV], zahtjevi br. 65731/01 i 65900/01, odluka od 6. srpnja 2005.

48. Stran Greek Refineries $i$ Stratis Andreadis protiv Grčke, zahtjev br. 13427/87, presuda od 9. prosinca 1994.

49. Suljagić protiv Bosne i Hercegovine, zahtjev br. 27912/02, presuda od 3. studenog 2009.

50. Tilocca protiv Hrvatske, presuda od 5. travnja 2018., zahtjev br. 40559/12, presuda od 5. travnja 2018.

51. Tre Traktorer Aktiebolag protiv Švedske, zahtjev br. 10873/84, presuda od 7. srpnja 1989.

52. Valette i Doherier protiv Francuske, zahtjev br. 6054/10, odluka od 29. studenog 2011.

53. Vučak protiv Hrvatske, zahtjev br. 889/06, presuda od 23. listopada 2008. 


\author{
Gabrijela Mihelčić* \\ Maša Marochini Zrinski**
}

Summary

\section{TEMPORARY ADMINISTRATION OF PROPERTY IN THE LIGHT OF THE RIGHT TO PEACEFUL ENJOYMENT OF PROPERTY}

In the paper, the authors analyse the institute of temporary administration of property in general, but also in selected special regimes. The first part of the paper gives an overview of the genesis of the institute, followed by its assumptions and features. The requirements required for the establishment of temporary administration of property in the national system are discussed, that is, when the owner has been asked to make certain doing which he has not done, all in relation to the protection of certain goods. Furthermore, the features of the temporary nature and limitations of the enforcement of property rights have been analysed in the light of the features of the protection of the right to peaceful enjoyment of property. The paper placed an emphasis on the third rule of the right to peaceful enjoyment of property: the control of the use of property. What has been analysed is whether temporary administration violates a fair balance, i.e. whether the restrictions imposed by the state are within its margin of appreciation and proportionate.

Keywords: temporary administration; right to peaceful enjoyment of property; proportionality.

Zussamenfassung

\section{SEQUESTRATION DER IMMOBILIE IM LICHTE DES SCHUTZES DES RECHTS AUF ACHTUNG DES EIGENTUMS}

Der Beitrag analysiert das Institut der vorläufigen Verwaltung der Immobilie bezüglich deren allgemeinen Regelung sowie auch bezüglich der ausgewählten besonderen Regelungen. Im ersten Teil des Beitrags stellt man die Genese des Instituts und seine Voraussetzungen und Eigenschaften dar. Die Anforderungen für

* Gabrijela Mihelčić, Ph.D., Associate Professor, University of Rijeka, Faculty of Law; gabrijela@pravri.hr.

** Maša Marochini Zrinski, Ph.D., Assistant Professor, University of Rijeka, Faculty of Law; mmarochini@pravri.hr. 
vorläufige Verwaltung im nationalen Recht werden hervorgehoben, beziehungsweise die Tatsache, dass man vom Eigentümer eine bestimmte Handlung in Bezug auf den Schutz bestimmter Güter verlangte, was er verweigerte. Anschließend werden die Merkmale der Vorläufigkeit und Einschränkung der Ausübung von eigentumsrechtlichen Befugnissen auf einer Sache bezüglich der Merkmale des Schutzes des Rechts auf Achtung des Eigentums analysiert. Es wird betont, dass es sich dabei um die dritte Regel über die Kontrolle der Vermögennutzung handelt. Man versuchte festzustellen, ob manche Regelungen das gerechte Gleichgewicht zerstört haben, beziehungsweise, ob die vom Staat aufgezwungenen Beschränkungen im Rahmen des Ermessensspielraums verhältnismäßig (proportional) sind.

Schlüsselwörter: vorläufige Verwaltung; das Recht auf Achtung des Eigentums; Verhältnismäßigkeit.

Riassunto

\section{IL SEQUESTRO DELL'IMMOBILE ALLA LUCE DELLA TUTELA DEL DIRITTO AL PACIFICO GODIMENTO DEL PATRIMONIO}

Le autrici nel lavoro analizzano l'istituto del sequestro di bene immobile nel regime giuridico generale ed in alcuni regimi speciali. Nella prima parte del lavoro si offre una rassegna dell'istituto giuridico, mentre nel prosieguo se ne disaminano i presupposti e le caratteristiche. Si evidenziano i requisiti necessari per il sequestro nella disciplina nazionale, ovvero che al titolare del diritto di proprietà sia richiesta una determinata azione che costui non ha posto in essere al fine di tutelare determinati beni. Di seguito vengono esaminate le caratteristiche della temporaneità e della limitazione dell'esercizio dei poteri in capo al proprietario sul bene in relazione al significato della tutela del pacifico godimento del patrimonio. Si rileva come si tratti della terza regola sul controllo dell'uso del patrimonio e s'è valutato se ciò porti ad incrinare l'equilibrio giuridico; cioè se le limitazioni imposte dallo Stato siano proporzionate.

Parole chiave: sequestro; diritto al pacifico godimento del patrimonio; proporzionalità. 